\title{
PROGRAM EMOTIONAL SPIRITUAL ACHIEVEMENT (ESA) DALAM MEMBENTUK POLA PIKIR SISWA PADA MATA PELAJARAN PENDIDIKAN AGAMA ISLAM DI KOTA TANGERANG SELATAN
}

\author{
E. Kurniyati \\ etykurniyati63@gmail.com
}

Kantor Kementrian Agama Kota Tangerang Provinsi Banten

\author{
Abdul Basyit \\ abdulbasyit@umt.ac.id \\ Pendidikan Agama Islam, Fakultas Agama Islam, Universitas Muhammadiyah Tangerang, Jl. \\ Perintis Kemerdekaan I Babakan No.33 Tangerang-Banten
}

\begin{abstract}
This study aims to describe the implementation of the Emotional Spiritual Achievement (ESA) Program in shaping students' mindsets towards Islamic Religious Education. The results of this study are expected to provide solutions for schools, in realizing a good education with good morals and good character. This research was conducted using qualitative methods with observation, interviews, and documentation techniques. The data that has been collected is analyzed through data reduction, data display, data validity and conclusions. This study shows that: 1) The Emotional Spiritual Achievement (ESA) program is very important to be followed and implemented by schools. 2) The role of Islamic Religious Education teachers is very important for the development of emotional and spiritual intelligence of students in schools. 3) The role of Islamic Religious Education teachers in developing the Emotional Spiritual Achievement (ESA) Program has been very good so that it can produce good output and character.
\end{abstract}

Keywords: ESA, Student Mindset, Islamic Religious Education.

\begin{abstract}
ABSTRAK
Penelitian ini bertujuan untuk mendeskripsikan pelaksanaan Program Emosional Spiritual Achievement (ESA) dalam membentuk pola pikir siswa terhadap Pendidikan Agama Islam. Hasil penelitian ini diharapkan dapat memberikan solusi bagi sekolah, dalam mewujudkan pendidikan yang baik bermoral dan berkarakter baik. Penelitian ini dilakukan menggunakan metode kualitatif dengan teknik observasi, wawancara, dan dokumentasi. Data yang telah terkumpul dianalisa melalui reduksi data, display data, keabsahan data dan kesimpulan. Penelitian ini menunjukkan bahwa: 1) Program Emosional Spiritual Achievement (ESA) sangat penting di ikuti dan dilaksanakan oleh sekolah. 2) Peran guru Pendidikan Agama Islam sangat penting terhadap perkembangan kecerdasan emosional dan spiritual siswasiswi di sekolah. 3) Peran guru Pendidikan Agama Islam dalam mengembangkan Program Emosional Spiritual Achievement (ESA) sudah sangat baik sehingga dapat menghasilkan output yang baik dan berkarakter.
\end{abstract}

Kata Kunci: ESA, Pola Pikir Siswa, Pendidikan Agama Islam. 


\section{A. Pendahuluan}

Pendidikan Islam adalah usaha pendewasaan manusia seutuhnya (lahir dan batin) dalam arti tuntunan yang menuntut peserta didik untuk memiliki kemerdekaan berfikir, merasa, bertindak dan berbicara serta percaya pada diri sendiri dengan penuh rasa tanggung jawab dalam setiap tindakan dan perilaku kehidupan sehari-hari yang telah ditentukan dalam agama Islam. ${ }^{1}$ Pendidikan Agama Islam di sekolah atau madrasah dalam pelaksanaannya masih menunjukkan berbagai persoalan, seperti dikemukakan oleh Dirjen Kelembagaan Agama Islam Departemen Agama bahwa Islam diajarkan lebih pada hafalan (padahal Islam penuh dengan nilainilai yang harus dipraktekkan), penalaran dan argumentasi berfikir untuk masalah-masalah agama kurang mendapat perhatian, penghayatan nilai-nilai agama kurang mendapat perhatian, penghayatan nilai-nilai agama kurang mendapat penekanan, menatap lingkungan untuk kemudian memasukkan nilai Islam sangat kurang mendapat perhatian (orientasi pada kenyataan kehidupan seharihari kurang), dan pendidikan agama belum dijadikan fondasi pendidikan karakter peserta didik dalam perilaku keseharian. ${ }^{2}$

Menurut Prof. Abudin Nata pendidikan Islam adalah upaya membimbing, mengarahkan, dan membina peserta didik-an yang dilakukan secara sadar dan terencana agar terbina suatu kepribadian yang utama sesuai dengan nilai-nilai ajaran Islam. Tujuan ini secara hirarkis bersifat ideal, bahkan universal. Tujuan tersebut dapat dijabarkan pada tingkat yang lebih rendah lagi, menjadi tujuan yang bercorak nasional, institutional, perbidang studi, per pokok ajaran, sampai dengan setiap kali melaksanakan kegiatan belajar mengajar. ${ }^{3}$ Agama Islam tidak semata-

\footnotetext{
${ }^{1}$ Abdul Basyit dan Sahlani, Ilmu Pndidikan Islam, (Banten: Pustaka Getok Tular: 2017), h. 9

${ }^{2}$ Abdul Majid dan Andayani, Pendidikan Agama Islam Berbasis Kompetensi, (Bandung: Remaja Rosda Karya, 2005), h. iii

${ }^{3}$ Abudin Nata, Metodologi Studi Islam, (Jakarta: Rajawali pers, 2013), h. 340
}

mata berkomponen ritus, namun disetiap jengkal persoalan umat seperti ekonomi, sosial, politik, dan kebudayaan semuanya dituntut keberangkatan dari agama. Islam bukan hanya peraturan dan hukum-hukum saja melainkan juga ilmu, cinta kasih dan yang paling mengesankan bahwa kecerdasan emosi atau yang dikenal dengan Emosional Quotient atau EQ dan kecerdasan Spiritual SQ adalah dasar dari agama Islam. Merujuk kepada pembahsan diatas, kecerdasan emosional sangat penting dikembangkan di sekolah karena kecerdasan ini tidaklah berkembang secara alamiah. Kematangan emosi seseorang tidak semata-mata didasarkan pada perkembangan biologisnya, tetapi tergantung pada proses pendidikan, pelatihan dan bimbingan yang terus menerus. Emosi anak sering kali berbeda dengan orang dewasa, terlebih pada anak yang baru menginjak masa remaja, ciri khas emosi anak yaitu emosi takut dan marah yang berlebihan, hal ini menjadi faktor fundamental bagi emosi anak.

Kecerdasan emosional tidaklah ditentukan sejak lahir, melainkan dapat dipupuk dan dikembangkan dalam diri anak melalui pembinaan sehari-hari dan terus dibawa ketika berinteraksi dengan orang lain sampai dewasa kelak. Keluarga dan sekolah seharusnya berperan aktif dalam memberikan stimulus melalui penanaman nilai-nilai yang baik dan tepat serta dapat menciptakan emosi anak yang positif agar kecerdasan emosioanl matang. Lingkungan pertama yang dikenal oleh anak adalah keluarga, keluarga merupakan bentuk kecil kehidupan bersosial. Mendidik anak yang cerdas secara emosional dengan kemampuan mengenali emosi diri, mengelola emosi, memanfaatkan emosi secara produktif, empati dan kesanggupan membina hubungan menjadi bagian dari pendidikan agama Islam (PAI). Peran guru PAI sangatlah penting terhadap perkembangan emosi peserta didiknya disekolah, guru PAI memberikan bimbingan dan pengarahan dalam mendidik siswa agar menjadi manusia yang berakhlak mulia, disinilah peran pendidikan. 
Penyelenggara pendidikan di Indonesia menurut UU nomor 20 tahun 2003 pasal 1 ayat (2) di sebutkan bahwa suatu pendidikan nasional adalah pendidikan yang berdasarkan pancasila dan undang-undang dasar 1945 yang berakar pada nilai-nilai agama, kebudayaan nasional dan tanggap terhadap tuntunan perubahan zaman. Pernyataan tersebut menunjukkan bahwa sangat pentingnya pendidikan melalui proses pembelajaran khususnya pendidikan agama Islam menjadi sangat penting sebagai dasar utama dalam mengembangkan potensi diri yaitu dasar kekuatan spiritual sehingga mampu mewujudkan pengembangan akhlak yang mulia. Selain kecerdasan emosional, yang perlu diterapkan kepada anak adalah kecerdasan spiritual karena SQ tidak kalah pentingnya. Menurut Donah Zohar dan Ian Marshall kecerdasan spiritual dapat menumbuhkan fungsi manusia seseorang sehingga membuat mereka menjadi kreatif, luwes, berwawasan luas, spontan dan dapat menghadapi kecemasan ke khawatiran dan dapat menjembatani diri sendiri dan orang lain serta menjadi lebih cerdas secara spiritual dalam beragama. ${ }^{4}$

Kecerdasan spiritual ini lebih menekankan kepada moral anak untuk menjadikan manusia yang dapat berhubungan baik dengan penciptaannya serta kepada manusia baik dalam sosial maupun dalam hubungan beragama serta dapat menghargai dirinya sendiri untuk turut bertanggung jawab serta matang dalam menghadapi persoalan hidup. Pendidik harus memperhatikan bagaimana kondisi peserta didik mengenai kecerdasan emosional dan spiritual serta perkembangannya, pendidik dituntut untuk bisa mengantarkan peserta didiknya untuk menjadi manusia yang tidak hanya cerdas intelektual tetapi juga harus cerdas secara emosional dan spiritual.

Dalam hal ini perlu adanya tinjauan apakah guru di sekolah terutama guru PAI

${ }^{4}$ Umairso, Kepemimpinan dan Kecerdasan Spiritual, (Jogjakarta: Ar-Ruzz Media, 2011) h. 11 benar-benar dapat mengembangkan kecerdasan emosional dan spiritual siswa, serta bagaimana para guru dalam mengembangkan kecerdasan emosioanal dan spiritual anak. Kecerdasan intelektual (IQ) dan kecerdasan emosional (EQ) memiliki peran penting dalam kehidupan dan keberhasilan seseorang, namun harus digaris bawahi memiliki kecerdasan intelektual dan kecerdasan emosional saja belum cukup dalam menjalin kebahagiaan hidup. Sehingga perlu keseimbangan antara kecerdasan intelektual (IQ) dan kecerdasan emosional (EQ) dan kecerdasan spiritual (SQ). jika membiarkan kecerdasan intelektual dan emosional yang berkuasa dalam diri anak tanpa dilandasi dengan kecerdasan spiritual, maka akan mempengaruhi tumbuh kembang mental dan kejiwaan anak yang cendrung mengarah pada perilaku yang manusiawi serta jauh dari tuhan.Permasalahan yang sering terjadi disekolah tingkat menengah atas (SMA) maupun madrasah 'aliyah (MA) terutama dalam permasalahan emosionalnya adalah anak sering tidak bisa menahan emosinya dalam menghadapi permasalahn dengan teman-temannya dikelas maupun diluar kelas, masih sering mudah tersinggung, memiliki sensitive yang tinggi, kurang percaya diri, mudah terpengaruh oleh temannya dan egois mau menang sendiri.

Dengan permasalahan diatas sudah seharusnya pihak sekolah aktif melakukan pendekatan kepada seluruh siswa-siswi yang melakukan penyimpangan maupun tidak, karena peran guru sangat dibutuhkan dan sangat diharapkan bimbingannya oleh siswa maupun dari pihak orang tua demi tercapainya tujuan pendidikan yang di inginkan. Dengan semua ini merupakan tanggung jawab seluruh pihak sekolah yang termasuk dan yang terpenting di dalamnya adalah guru pendidikan agama Islam (PAI). Adapun tugas pokok guru agama adalah mendidik, membimbing dan mengajarkan peserta didik dalam mengajarkan ilmu pengetahuan agama ke dalam diri anak didik yang peranan utamanya adalah mengubah 
sikap, mental, dan moral anak agar beriman dan bertakwa kepada Tuhan yang Maha Esa serta mampu mengamalkan segala ilmunya. Sesuai yang saya ketahui sekolah SMAN 7 dan SMKN 1 Kota Tangerang Selatan adalah salah satu sekolah yang telah aktif mengikuti program Emotional Spiritual Achievement (ESA) dalam mengembangkan dan menanamkan kecerdasan emosi pada siswasiswinya. Pihak sekolah sangat mendukung dan menyetujui siswa-siswi SMAN 7 dan SMKN 1 Kota Tangerang Selatan untuk mengikuti program ESA dengan melibatkan guru-guru terutama guru PAI di dalamnya, sebagaimana yang telah disampaikan oleh kepala sekolah bahwasannya program ESA ini sangat bermanfaat dalam membentuk pola pokir siswa dalam belajar agama Islam

Terkait pembahasan di atas penulis sangat ingin dan sangat tertarik dalam meneliti ESA yang sudah di ikuti oleh sekolah SMAN 7 Kota Tangerang Selatan, untuk mendalami lebih dalam tentang program ESA yang akan penulis tuangkan dalam judul: "Program Emotional Spiritual Achievement (ESA) Dalam Membentuk Pola Pikir Siswa Pada Mata Pelajaran Agama Islam (PAI) Di Kota Tangerang Selatan"

\section{B. Kajian Teori}

\section{Pengertian Emosional}

Menurut Abdul Basyit salah satu dosen Universitas Muhammadiyah tangerang kecerdasan emosional menuntut diri untuk belajar mengakui dan menghargai perasaan diri sendiri dan orang lain dan untuk menganggapinya dengan tepat, menerapkan dengan efektif energi emosi dalam kehidupan dan pekerjaan sehari-hari. 3 (tiga) unsur penting kecerdasan emosional terdiri dari: kecakapan pribadi (mengelola diri sendiri); kecakapan sosial (menangani suatu hubungan) dan keterampilan sosial (kepandaian menggugah tanggapan yang dikehendaki pada orang lain). ${ }^{5}$

${ }^{5}$ Abdul Basyit, Kapita Selekta Pendidikan Islam, (Banten: Pustaka Getok Tular, 2016), h. 9-10
Emosional merupakan kemampuan mengenal emosi diri yaitu kemampuan menyadari perasaan sendiri pada saat perasaan itu muncul sehingga mampu memahami dirinya, dan mengendalikan dirinya, mampu membuat keputusan yang bijaksana sehingga tidak diperbudak oleh emosinya. Kemampuan mengelola emosi adalah kemampuan menyelaraskan perasaan emosi dengan hubungannya sehingga dapat memelihara harmoni kehidupan individunya dengan lingkungan atau orang lain. Menurut penelitian Daniel Goleman menunjukkan bahwa manusia mempunyai suatu jenis potensi dasar yang lain yaitu kecerdasan emosional. Menurut pendapatnya kecerdasan akan dapat secara efektif apabila seseorang mampu memfungsikan kecerdasan emosionalnya. ${ }^{6}$

Menurut Goleman kecerdasan emosional adalah kemampuan seseorang mengatur kehidupan emosinya dengan inteligensi (to manage ouremotional life with intelligence), menjaga keselarasan emosi dan pengungkapannya melalui keterampilan kesadaran diri, pengendalian diri, motivasi diri, empati dan keterampilan social. ${ }^{7}$ Reuven Bar-On menyebutkan kecerdasan emosi merupakan serangkaian kemampuan, kompetensi dan kecakapan non kognitif, yang mempengaruhi kemampuan seorang untuk berhasil mengatasi tuntutan dan tekanan lingkungan. ${ }^{8}$ Cooper dan A. Sawaf mendefinisikan kecerdasan emosi sebagai kemampuan merasakan, memahami, dan secara efektif menerapkan daya dan kepekaan emosi sebagai sumber energy, informasi,

\footnotetext{
${ }^{6}$ Daniel Goleman, Kecerdasan emosi Untuk Mencapai Puncak Prestasi, (Jakarta: Gramedia Puskta Utama, 2001), Cet IV, h. 18

${ }^{7}$ Daniel Goleman, Emotional intellengce, khususnya Bab 7 dan 8

${ }^{8}$ Steven J Stein, Ledakan EQ: 15 Prinsip Dasar Kecerdasan Emosional Meraih Sukses, (Bandung: Kaifa, 2002), h. 30
} 
koneksi dan pengaruh manusia. ${ }^{9}$ Sementara itu Hein menyatakan bahwa kecerdasan emosional adalah suatu bentuk kecerdasan yang berkaitan dengan sisi kehidupan emosi, seperti kemampuan untuk menghargai dan mengelola emosi diri dan orang lain. Untuk memotivasi diri seseorang dan mengekang impuls, dan untuk mengatasi hubungan interpersonal secara efektif. ${ }^{10}$

Adapun kecerdasan emosi menurut penulis adalah kapasitas, kemampuan, dan keterampilan untuk menangkap atau menilai serta mengendalikan emosi diri sendiri, orang lain dan kelompok. Kecerdasan emosi merupakan suatu bangunan yang bersatu yang tersusun atas lima dasar ikatan, yaitu pengetahuan, pengelolaan, hubungan, motivasi dan empati. Dan pengendalian perasaan atau emosi, kecerdasan emosi sendiri masih merupakan subjek penelitian yang mengungkapkan kenyataan bahwa ia berbeda dari kognitif atau teknis serta menggunakan bagian otak yang berbeda pula. yaitu sholat dan sabar. ${ }^{11}$ Dalam Al-Qur'an disebutkan bahwa dalam diri manusia ada dimensi yang cendrung kepada kebaikan dan kejahatan. Dua dimensi itu bertarung dalam setiap diri manusia. Pertarungan mengalahkan dimensi kejahatan itu dikenal sebagai jihad akbar. Untuk dapat mengalahkan dimensi kejahatan, manusia mempunyai dua senjata, yaitu sholat dan sabar:(QS. Al-Baqarah[2]: 45). ${ }^{12}$

Dalam perspektif para ahli kesehatan mental Islam. Istilah emosional sering disebut dengan kesehatan jiwa/mental (al-shihhah alnafsiyyah). Ahli kesehatan mental dalam Islam

${ }^{9}$ Cooper dan A. Sawaf, Kecerdasan Emosional dalam Kepemimpinan Organisasi, (Jakarta: Gramedia Pustaka Utama, 1998), h. 13

${ }^{10}$ Daniel Goleman, Kecerdasan Emosi

Untuk Mencapai Puncak Prestasi, (Jakarta: Gramedia Puskta Utama, 2001), h. 34

${ }^{11}$ Abdul Basyit, Kapita Selekta Pendidikan Islam, (Banten: Pustaka Getok Tular, 2016), h.6-7

${ }^{12}$ Kementrian Agama Republik Indonesia, Al-Qur'an dan Terjemah Al-Fattaah, (Depok: Yakfi, 2015), h. 7 seperti Mustafa Fahmi ${ }^{13}$ dan Abdul Aziz el Qussiy $^{14}$ mendefinisikan istilah tersebut dengan pengertian yang serupa dengan kecerdasan emosional. Bagi keduanya alshihhah al-nafsiyyah adalah kesehatan jiwa/mental yang dilandasi oleh pengenalan diri sendiri, sehingga ia dapat melakukan penyesuaian terhadap diri maupun masyarakat lingkungannya. Semetara itu, dalam pandangan Adz-zakiy kecerdasan emosional adalah hasil pengembangan dari berbagai potensi ketauhidan, baik tauhid uluhiyyah, rububiyyah, ubudiyyah dan khuluqiyyah. ${ }^{15}$

a) Faktor-faktor yang mempengaruhi Emosional

Para ahli berpendapat berkaitan dengan kecerdasan emosi pada anak usia dini sangat di tentukan oleh gaya pengasuhan para orang tuanya. Tentunya orang tua unggul bisa melakukan pengasuhan anak dengan akurat sehingga kecerdasan emosi anak betul-betul bisa sesuai atau minimal mendekati hasil yang diharapkan. Menurut Aisah Indiati ada dua faktor penting yang mempengaruhi perkembangan emosi seseorang yaitu: ${ }^{16}$

Pertama kematangan perilaku emosional. Perkembangan intektual seorang nantinya menghasilkan kemampuan untuk memahami makna yang sebelumnya tidak dimengerti, memperhatikan sesuatu rangasangan dalam jangka waktu lama, dan memutuskan ketegangan emosi pada satu objek. Kemampuan mengingat dan menduga mempengaruhi reaksi emosional sehingga anak menjadi kreatif terhadap rangsangan

\footnotetext{
${ }^{13}$ Mustafa Fahmi, Kesehtan Mental di Lingkungan Keluarga, Sekolah dan Masyarakat, (Jakarta: Bulan Bintang, 1997), h. 21

${ }^{14}$ Mustafa Fahmi, Pokok-Pokok Kesehatan Jiwa/Menta,l (Bulan Bintang, 1986), h. 15

${ }^{15}$ Hamdani Bakran Adz Zakiy, Kecerdasan Kenabian Menumbuhkan Potensi Hakiki Insani Melalui Pengembangan Kesehatan Ruhan, $i$ (Yogyakarta: Islamika, 2004), h. 41-45

${ }^{16}$ Purma Atmaja Prawira, Psikologi Pendidikan dalam Perspektif Baru, (Jogjakarta: ArRuzz Media, 2012), h. 164
} 
yang semula kurang atau tidak mempengaruhi dirinya.

Kedua kegiatan belajar. Faktor belajar dinilai lebih penting karena lebih mudah dikendalikan di banding faktor lain. Caranya adalah dengan mengendalikan positif lingkungan belajarnya guna menjamin pembinaan emosi anak. Pembinaan dengan belajar juga diupayakan dengan menghilangkan pola reaksi emosional yang tidak diinginkan. Ada lima jenis kegiatan belajar yang turut menunjang pola perkembangan emosi seseorang. Yaitu belajar coba ralat, belajar dengan cara meniru, belajar dengan cara identifikasi, belajar melalui pelatihan-pelatihan.

Pertumbuhan emosional dipengaruhi oleh beberapa faktor, antara lain:

1) lingkungan,

2) keluarga: orang tua adalah yang pertama kali harus mengajarkan kecerdasan emosi kepada anaknya dengan memberikan teladan dan contoh-contoh yang baik agar anak memiliki kecerdasan emosional yang tinggi.

3) Pengaruh faktor kematangan

Tiap organ dalam tubuh manusia mengalami pertumbuhan dan perkembangan, tiap organ (fisik maupun psikis) telah matang jika telah mencapai dengan sempurna.

b) Peran Emosional dalam kehidupan

Sama halnya dengan IQ, EQ juga memiliki peranan penting dalam kehidupan setiap individu. Dengan memiliki kecerdasan emosional yang bagus, setiap individu memiliki kemampuan untuk mengenal diri sendiri, kemampuan mengelola emosi, berhubungan dengan orag lain, mampu memiliki kesadaran akan emosi orang lain (mendengar, merasakan perasaan orang lain dari kata, bahasa tubuh maupun yang lain. Substansi dari kecerdasan emosional adalah kemampuan merasakan dan memahami untuk kemudian disikapi secara manusiawi. Orang yang Emosionalnya baik, dapat memahami perasaan orang lain, dapat membaca yang tersurat dan tersirat. Semua pembahasan tersebut akan menuntun agar bersikap sesuai dengan kebutuhan dan tuntunan lingkungannya. Kecerdasan emosional mengajarkan tentang integritas kejujuran, komitmen, visi, kreatifitas, mental dan kebijaksanaan dan pengasuhan. Oleh karena itu, emosional mengajarkan bagaimana manusia bersikap terhadap dirinya dan terhadap orang lain.

\section{Pengertian Spiritual}

Kecerdasan spiritual diyakini sebagai kecerdasan yang paling utama dibandingkan dengan berbagai kecerdasan lainnya. Kata spiritual memiliki akar kata spirit yang berarti roh, kata ini berasal dari bahasa latin spiritus yang berarti napas. Spiritual berarti pula segala sesuatu diluar fisik, termasuk pikiran, perasaan dan karakter manusia. Kecerdasan spiritual berarti kemampuan seseorang untuk dapat mengenal dan memahami diri seseorang sepenuhnya sebagai makhluk spiritual maupun sebagai bagian dari alam semesta, spiritual menjadi landasan yang diperlukan untuk memfungsikan intektual dan emosional secara efektif dan menyeluruh. Melalui spiritual pemikiran, perilaku dan hidup manusia diberi makna dan bermuatan spiritual. Orang yang cerdas secara spiritual tidak akan bunuh diri. Mengutip HD Bastaman yang mengetengahkan kisah Victor Frankl (MD \& PhD), seorang keturunan Yahudi yang menjadi supervisor dari empat kampus konsentrasi NAZI Jerman (Auschwitz dII). Diam-diam Frankl melakukan semacam konseling dan psikoterapi kepada sesama tahanan yang putus asa dan berniat mengakhiri hidup.

Frankl menyadarkan mereka untuk optimis dan menaruh harapan tentang kemungkinan adanya perubahan situasi, dan mengingatkan mereka terhadap hal-hal yang bermakna bagi mereka, seperti keluarganya yang menanti di luar, kebajikan-kebajikan yang dapat dilakukan, dan keimanan kepada Tuhan. Frankl mengungkapkan adanya hikmah di balikmusibah, adanya makna dalam cerita, 
(meaning in the suffering). ${ }^{17} \mathrm{M}$. Usman Najati mengungkapkan bahwa dorongan spiritual adalah dorongan yang berhubungan aspek spiritual dalam diri manusia, seperti dorongan untuk beragama, taqwa, cinta kebajikan, kebenaran dan keadilan, benci terhadap kejahatan, kebathilan, dan kedzaliman. Sependapat dengan hal tersebut, dikutip dalam bukunya M. Usman Najati, A. Maslow mengatakan bahwa kebutuhan spiritual manusia merupakan kebutuhan alami yang integritas, perkembangan dan kematangan individu sangat tergantung pada pemenuhan kebutuhan tersebut. ${ }^{18}$ Pandangan lain juga dikemukakan oleh Muhammad Zuhri, bahwa spiritual adalah kecerdasan manusia yang digunakan untuk berhubugan dengan Tuhan. Asumsinya jika hubungan seseorang dengan Tuhan berjalan baik, maka bisa dipastikan hubungan desan sesame manusia akan baik pula. ${ }^{19}$ Berdasarkan beberapa pendapat di atas, dapat ditarik kesimpulan bahwa kecerdasan spiritual dalam pandangan Islam adalah kecerdasan yang berpusatkan pada rasa cinta yang mendalam kepada Allah dan seluruh ciptaan-Nya. Bentuk cinta Allah SWT dan ciptaan-Nya harus terimplementasi dalam kehidupan sehari-hari dalam bentuk menjalankan perintah dan menjauhi laranganNya.

a) Faktor-faktor yang mempengaruhi Spiritual

Faktor-faktor yang mempengaruhi tingkat kecerdasan spiritual seseorang adalah antara lain sumber kecerdasan itu sendiri (God Spot), potensi qalbu (hati nurani), dan kehendak nafsu. Sedangkan secara umum faktor utama yang dapat mempengaruhi kecerdasan spiritual seseorang adalah faktor lingkungan yang lebih khususnya didominasi

\footnotetext{
${ }^{17}$ Abdul Basyit, Kapita Selekta Pendidikan Islam, (Banten: Pustaka Getok Tular, 2016), h. 12

${ }^{18} \mathrm{M}$. Usman Najati, Al-Qur'an dan Psikolog, (Jakarta: Asas Pustaka, 2001), h. 15

${ }^{19}$ Danah Zohar dan Ian Marshall, $S Q$ : memanfaatkan kecerdasan spiritual Dalam Berpikir Integritas dan Holistik untuk Memaknai Kehidupan, (Bandung: Mizan, 2001), h. 27
}

oleh peran orang tua dalam membina kecerdasan anak dalam keluarga.

1) God Spot. Prof. V.S. ramachandran telah berhasil mengidentifikasikan God Spot dalam otak manusia yang merupakan pusat spiritual antara jaringan saraf dan otak. $^{20}$ Dalam penelitiannya dia menemukan adanya bagian dalam otak yaiu lobus temporal yang meningkatnya sebagai titik Tuhan atau God Spot. Titik Tuhan memainkan peran biologis yang menentukan dalam pengalaman spiritual.

2) Potensi Qalbu (hati nurani). Menggali potensi qolbu secara klasik sering dihubungkan dengan "polemos" amarah "emosi" cinta dan "logos" pengetahuan. ${ }^{21}$ Padahal dimensi qalbu tidak hanya mencakup atau dicakup dengan pembatasan kategori yang pasti. Menangkap dan memahami pengertiannya secara utuh adalah mustahil, itu hanyalah sebagai asumsi dari proses perenungan yang sangat personal karena didalam qalbu terdapat potensi yang sangat multi dimensional. Diantaranya adalah: a)Fu'ad yang berhubungan dengan indrawi. b) Shadr dinding hati yang menerima limpahan cahaya keindahan. c) Hawaa yang mengarahkan kepada kemauan.

3) Kehendak Nafsu. Nafs adalah muara yang menampung hasil oleh fu'ad, shadr, dan hawaa yang kemudian menampakkan dirinya dalam bentuk perilaku nyata dihadapan manusia lainnya. Nafs merupakan keseluruhan atau totalitas dari manusia itu sendiri, apabila nafs mendapatkan pencerahan dari cahaya qalbu maka dinding biliknya benderang memantukan binar-binarkemuliaan. Jiwa nafs yang melangit, merindu dan menemukan kehangatan cinta ilahi. ${ }^{22}$

${ }^{20}$ Ary Ginanjar agustian, ESQ Power, (Jakarta: Arga, 2002), h. 44

${ }^{21}$ Toto Tamara, Kecerdasan Ruhaniah, (Jakarta: gema Insani press,2001), h. 93

${ }^{22}$ Abdul Jalil, Spiritual Entrepreneurship, (Yogyakarta: Lkis, 2013), h. 5 
b) Peran Spiritual dalam kehidupan setiap individu $^{23}$

Sehebat apapun manusia dengan kecerdasan intelektual maupun kecerdasan emosional, pada saat-saat tertentu melalui pertimbangan afektif, kognitif dan konatifnya, manusia akan meyakini dan menerima tanpa keraguan bahwa di luar dirinya ada sesuatu kekuatan yang maha Agung yang melebihi apapun, termasuk dirinya. Menurut danah zohar bahwa IQ bekerja untuk melihat keluar (mata pikiran) dan EQ bekerja mengolah yang di dalam (telinga perasaan), maka SQ menunjukkan pada kondidi pusat diri. Orang yang ber-SQ tinggi memaknai penderitaan hidup dengan memberi makna positif pada setiap peristiwa, masalah, bahkan penderitaan yang didalamnya. Kecerdasan spiritual menyadarkan seseorang akan tujuan hidup dan pemaknaan kehidupan yang dijalaninya. Bahwa hidup memiliki arah dan tujuan hidup, bahwa setiap kehidupan memiliki pemaknaan yang tidak sekedar makna-makna yang bersifat duniawi. Kecerdasan ini menjadi pedoman, arah dan tujuan hidup untuk menjalani kehidupan.

\section{Pengertian Achievement}

Dalam Kamus Bahasa Inggris arti kata Achievement adalah prestasi atau sesuatu yang berhasil dicapai. ${ }^{24}$ Prestasi adalah sebuah hasil yang telah dicapai oleh seseorang dalam melakukan usaha atau kegiatan, baik dalam kegiatan belajar mengajar, dalam sebuah program dan lain sebagainya. Prestasi adalah sebuah kemampuan nyata yang merupakan hasil dari berbagai faktor yang mempengaruhi baik dari dalam maupun dari luar individu dalam belajar. Selanjutnya prestasi yang telah dicapai berkaitan erat dengan motivasi berprestasi yaitu keinginan untuk berkembang, mengatasi berbagai hal tantangan termasuk dalam pendidikan.

${ }^{23}$ Danah Zohar dan Ian Marshall, SQ: memanfaatkan kecerdasan spiritual Dalam Berpikir Integritas dan Holistik untuk Memaknai Kehidupan, (Bandung: Mizan, 2001), h. 167

${ }^{24}$ Djohan Untung, Kamus Lengkap Inggris-Indonesia, (Edumasa Indonesia: 2006)
Berprestasi merupakan suatu hal yang ada dan dibawa sejak lahir, namun dalam banyak hal berprestasi harus didorong dengan motivasi yaitu dengan dikembangkan, ditumbuhkan dan dipelajari melalui suatu program atau pendidikan yang lain.

Sebagaimana penulis telah berdiskusi dengan ketua panitia Program Emosional Spiritual Achievement (ESA) dalam diskusi kami membahas nama tentang Achievement yang mana nama ini dipakai sebagai nama program, yang mengartikan bahwa Achievement ini adalah sebuah motivasi prestasi, dalam artian "memotivasi para siswasiswi yang mengikuti program ESA untuk menjadi pelajar yang berkarakter, bermoral baik, yang tentunya untuk menumbuhkan kecintaan kepada Tuhannya, membenarkan adanya Tuhan dan ajaran-Nya"

Memotivasi untuk berprestasi juga sebagai suatu yang berhubungan dengan pencapaian standar yang optimal dan baik. Untuk mencapai tujuan dan target yang telah ditentukan tentu membutuhkan motivasi yang baik, maka dari itulah ESA menggunakan kata Achievement sebagai motivasi untuk mencapai sebuah prestasi yang akan dicapai.

\section{Pengertian Pola Pikir}

Setiap pribadi manusia memiliki pola pikir yang beragam, yang terbentuk selama proses hidupnya, melalui kejadian-kejadian, pengalaman, proses pendidikan di bangku sekolah maupun dikeluarga dan melalui interaksi dengan sesama. Pola pikir ini akan sangat mempengaruhi respon, sikap dan tindakan setiap pribadi atas permasalahan yang dihadapinya. Terkadang seseorang kesulitan dalam merespon/menyikapi permasalahan yang dihadapi karena pola pikir yang ada membatasi dirinya untuk mencari pemecahan yang lebih baik.

Pola pikir atau yang kerap disebut minsed, yaitu bagaimana cara pandang seseorang. Merujuk pada kata berpikir maka mencakup beberapa hal seperti pikiran dan penalaran. Pikiran yang dalam bahasa inggris berarti mind memiliki beberapa pengertian yaitu: 1) kesadaran, keinsyafan, daya rasional, 
nalar manusia, kemampuan untuk bernalar, 2) psikis atau jiwa, diri, ego, identitas peribadi, 4) roh, subtansi rohani, 5) apa yang bertahan dalam seluruh perubahan kesadaran (pengalaman, kesadaran), 6) entitas yang memperlihatkan fungsi-fungsi seperti menyerap, mengamati, mengingat, membayangkan, memahami, merasa, membangkitkan emosi, menghendaki, menalar, mengadakan suatu perhitungan menuju kesuatu masa depan

Pola Pikir atau mindset
adalah sekumpulan kepercayaan (belief) atau cara berpikir yang mempengaruhi perilaku dan sikap seseorang, yang akhirnya akan menentukan level keberhasilan hidupnya. (Adi W.Gunawan dalam Yoga, 2008). ${ }^{25}$ Adi meyakini bahwa belief menentukan cara berpikir, berkomunikasi dan bertindak seseorang. Dengan demikian jika ingin mengubah pola pikir, yang harus diubah adalah belief atau kumpulan belief. Dweck, 2008, mengatakan bahwa "Pandangan yang orang adopsi untuk dirinya sangat mempengaruhi cara orang tersebut mengarahkan kehidupan". Artinya kepercayaan atau keyakinan seseorang memiliki kekuatan yang dapat mengubah pikiran, kesadaran, perasaan, sikap, dan lainlain, yang pada akhirnya membentuk kehidupannya saat ini. Menurut Simon pola pikir dibedakan menjadi dua, yaitu pola pikir negatif dan pola pikir positf. Pola pikir negatif berhubungan dengan cara pandang seseorang terhadap permasalahan yang dihadapi sebagai suatu hambatan atau kegagalan, sementara pola pikir positif berhubungan dengan cara pandang seseorang terhadap permasalahan yang dihadapi sebagai suatu peluang atau kesuksesan yag tertunda ${ }^{26}$

Pola pikir adalah kepercayaan atau sekumpulan kepercayaan atau cara berpikir

\footnotetext{
${ }^{25}$ Rahmatsogiharto.blogspot.com, Akses tgl 16-05-2019, jam 6:09 AM

${ }^{26}$ Muhamad Naufal, "Pergeseran Pola Pikir Tokoh Utama dalam Novel Ketika Elang Pergi ke Sarang" (Skripsi Universitas Semarang, 2015), h. 24
}

yang mempengaruhi perilaku dan sikap seseorang yang akhirnya menentukan level keberhasilan hidupnya. Setiap manusia pasti memiliki ide, pendapat, rencana, serta citacita itu semua diolah oleh otak, akal, pikiran dan selalu dipengaruhi oleh sikap dan perilaku. Pola pikir merupakan sistem kepercayaan atau kebiasaan yang diciptakan secara tradisional atau melalui hasil analisis pikiran sadar manusia yang tersimpan dalam alam bawah sadar. Karena pola pikir itu suatu kunci sukses terpenting dalam kehidupan manusia. Mindset atau sistem kepercayaan itulah hasil analisis pikiran sadar manusia yang tersimpan dalam pikiran bawah sadar ${ }^{27}$

\section{Jenis-jenis Pola Pikir}

Carol S. Dweck, dalam bukunya Change Your Mindset atau Change Your Life mengatakan bahwa pada dasarnya ada dua jenis pola pikir manusia, yaitu pola pikir tetap dan pola pikir berkembang, dari kedua jenis tersebut diantaranya sebagai berikut:

a. Pola pikir tetap (Fixed Mindset). Pola pikir tetap (fixed mindset) atau sering juga disebut pola pikir statis, tipe pola pikir ini didasarkan pada pandangan dan keyakinan bahwa kualitas diri atau daya intelektualitas seseorang adalah sesuatu yang sudah ditentukan, sesuatu yang sudah ditakar dan karena itu tidak dapat dikembangkan dan ditingkatkan lagi. Pandangan yang mendasar dalam pola pikir ini mengatakan bahwa segala sesuatu itu jika dalam hidupnya mengalami kegagalan berarti dianggap seseorang yang tidak memiliki kecerdasan. Karena itu, seseorang harus menjaga jati dirinya, bagaimanapun caranya agar tetap dianggap sebagai orang yang cerdas atau orang yang berhasil, dan hal ini diperoleh dengan cara menghindari kegagalan atau kebodohan itu sendiri. Pada dasarnya orang-orang semacam ini memiliki citra diri yang rendah, atau tergolong orang yang memiliki pandangan hidup pesimistis.

${ }^{27}$ P. Ratu Ile Tokan, Manjemen Peneliti Guru, (Jakarta : PT Grasindo, 2016), h. 253 
Dalam hal ini tidak berhadapan dengan situasi kegagalan atau situasi-situasi yang kurang menguntungkan, bahwa pada dasarnya adalah orang-orang yang optimis, cerdas, dan menarik sebagaimana orang yang memiliki pola pikir berkembang growth mindset). ${ }^{28}$ Jadi kesimpulan pola pikir tetap yaitu pola pikir yang tidak dapat ditingkatkan. Misalnya bersikap negatif, pesimis, tidak percaya diri, puas dengan keadaan yang sekarang

b. Pola pikir berkembang (Growth Mindset). Pola pikir berkembang (growth mindset) ialah pola pikir yang melihat potensi maupun kelemahan diri serta kejadian yang menimpa sebagai proses belajar. Ini kebalikan pola pikir statik yang menganggap bakat dan kejadian sebagai "nasib" yang tidak bisa diubah. ${ }^{29}$ Pola pikir berkembang (growth mindset) sering disebut juga dengan pola pikir dinamis. Pola pikir ini sebaliknya didasarkan pada pandangan dan keyakinan bahwa kualitas diri dan daya intelektualitas seseorag adalah sesuatu yang dapat terus dikembangkan dan ditingkatkan. Namun dalam hal ini lebih menekankan kepada tantangan yang harus dihadapi, sesuatu yang harus ditangani, sesuatu yang harus dilalui agar menadapat pembelajaran Dalam proses growth mindset ini bahwasanya sebuah kesalahan adalah sebuah perilaku yang masih dapat diperbaiki melalui sebuah proses pembelajaran yang dapat membawa kita menuju keberhasilan. Oleh karena itu sama sekali ia tidak berkaitan dengan citra diri atau siapa diri kita. Jadi dapat disimpulkan bahwa pola pikir berkembang yaitu pola pikir (pandangan) yang dapat

${ }^{28}$ Alexander Paulus, Your Thinking Determines Your Success: Rahasia menemukan Makna Kehiduan Menuju Keberhasilan, (Jakarta : Pt Gramedia Pustaka Utama, 2010), h. 84-92

${ }^{29}$ Risfan Munir, Manajemen Apresiatif : Melejitkan Potensi Diri Dalam Karier dan Bisnis Melalui Sikap Penghargaan, (Bandung : PT Mizan, 2011), h. 10 dikembangkan melalui praktik, pelatihan, cara atau metode yang tepat. Misalnya, sikap yang positif dan optimis, selalu ingin berusaha, berjuang terus, percaya bahwa bisa lebih maju Sedikitnya ada empat faktor yang mempengaruhi pola pikir seseorang, menurut Soegiharto (2013), yaitu lingkungan keluarga, pergaulan dengan masyarakat, pendidikan, dan sistem kepercayaan atau keyakinan:

1) Lingkungan Keluarga. Keluarga yang mengembangkan kebiasaan makan bersama, membaca buku, sholat tepat waktu, berakhlak baik, mematikan lampu setelah selesai digunakan, dan kebiasaan positif lainnya, akan menghasilkan anggota keluarga yang memiliki pola pikir yang terwarnai oleh nilai-nilai yang dibangun bersama oleh keluarga tadi. Pola pikir seseorang yang berasal dari keluarga yang sarat dengan sistem nilai positif, dipastikan akan lebih unggul dari keluarga yang tidak atau kurang membangun sistem nilainya.

2) Pergaulan dengan Masyarakat. Seseorang yang banyak berteman dengan pengusaha, cenderung memperlihatkan pola pikir seperti pengusaha. Seseorang yang berteman dengan politikus, cenderung akan mengikuti gaya berpikir politikus. Seseorang yang berteman dengan tukang rumpi, dia akan tertular dengan kegatalannya para perumpi. Dan bila seseorang berteman dengan orang yang sholeh, diapun cenderung akan mengadopsi sifat-sifat dan cara berpikir orang sholeh tersebut. Konsekuensinya, bila seorang ingin memiliki pola pikir yang baik, ia akan berhati-hati dalam memilih teman, karena teman dan lingkungan masyarakat bisa mempengaruhi seseorang

3) Pendidikan. Pendidikan adalah solusi terbaik untuk membentuk pola pikir yang unggul. Seseorang tidak akan 
membiarkan waktunya berlalu tanpa membaca buku. la akan rajin mencharge dirinya sendiri melalui seminar-seminar yang bermanfaat. la akan gunakan internet untuk mencari berbagai informasi yang dapat mendukung karirnya sebagai seseorang yang memiliki nilai positif. la akan berusaha untuk meningkatkan pendidikannya ke jenjang yang lebih tinggi, bukan karena selembar ijazah atau kebanggaan menyandang sederet gelar akademik, tapi karena kesadaran untuk terus meningkatkan kompetensi diri. la pun tidak akan membiarkan dirinya menonton TV lebih dari satu jam sehari.

4) Sistem Kepercayaan (Belief System). Faktor yang paling dominan mempengaruhi pola pikir adalah sistem kepercayaan atau keyakinan seseorang (belief system). Bukti sangat kuat bahwa sistem keyakinan memberikan pengaruh yang paling dominan terhadap pola pikir seorang, adalah ketika ia dihadapkan pada peluang melakukan korupsi. Satusatunya yang sanggup mencegah perbuatan tersebut bukanlah sanksi dari atasan, KPK, Kejaksaan atau dari Kepolisian, tetapi rasa takutnya kepada Tuhannya. Bahwa suatu hari nanti, setiap orang akan dibalas sesuai dengan apa yang diperbuatnya. la merasa tidak akan sanggup menghadapi murka Tuhan Yang Maha Keras siksanya atas korupsi yang ia lakukan. la juga sadar bahwa azab neraka, bukanlah akhir kehidupan yang baik. Belief System, atau sistem kepercayaan, atau sistem keyakinan, juga mampu mengarahkan seseorang untuk memberikan pelayanan terbaik kepada semua orang yang berurusan dengannya, baik itu masyarakat, sekolah, sahabat, atau saudara. Jadi, keyakinan dalam diri seseorang menentukan pola pikiran dan menentukan tindakannya. Berdasarkan beberapa definisi yang telah dijelaskan, maka pola pikir berkenaan dengan tanggapan atau cara pandang seseorang terhadap dunia eksternal atau sesuatu di luar dirinya yang bersifat riil dan merupakan kombinasi dari pancaindera yang dimilikinya. Cara pandang dapat berupa pengetahuan atau pemahaman akan sesuatu. Dengan demikian pola pikir siswa terhadap pendidikan agama Islam akan berdampak positif, tidak hanya dibuat suatu pelajaran yang biasa bahkan hanya sekedar belajar namun tidak ada bekas dan pelaksanaannya di dalam kehidupan sehari-hari. Dan sudah seharusnya para anak didik menjadikan pendidikan agama Islam sebagai pedoman dalam berperilaku keseharian karena di dalam pendidikan agama Islam sudah jelas sumber yang di jadikan pedoman yaitu adalah Al-Qu'an dan Sunnah.

\section{Pengertian Pendidikan Agama Islam}

Pengertian pendidikan itu bermacammacam, hal ini disebabkan karena perbedaan filsafah hidup yang dianut dan sudut pandang yang memberikan rumusan tentang pendidikan itu. Pendidikan merupakan suatu proses generasi muda untuk dapat menjalankan kehidupan dan memenuhi tujuan hidupnya secara lebih efektif dan efesien. Pendidikan lebih daripada pengajaran karena pengajaran sebagai suatu proses transfer ilmu belaka, sedang pendidikan merupakan transformasi nilai dan pembentukan kepribadian dengan segala aspek yang dicakupnya. Dalam spektrum makro, pendidikan diartikan sebagai merupakan proses pendewasaan anak melalui berbagai program dan kegiatan dalam konteks, baik formal maupun non formal. Dan hasil akhir pendidikan adalah pembentukan insan yang berkualitas, berakhlak mulia, beriman dan bertakwa kepada Tuhan yang Maha Esa, 
mandiri dan berguna bagi sesama manusia, masyarakat dan bangsanya. ${ }^{30}$

Perbedaan pendidikan dan pengajaran terletak pada penekanan pendidikan terhadap pembentukan kesadaran dan kepribadian anak didik disamping transfer ilmu dan keahlian. Pengertian pendidikan secara umum yang dihubungkan dengan Islam sebagai suatu system keagamaan menimbulkan pengertianpengertian baru yang secara implicit menjelaskan karakteristik-karakteristik yang dimilikinya pengertian pendidikan dengan seluruh totalitasnya dalam konteks Islam inheren dengan konotasi istilah "tarbiyah, ta'lim, dan ta'dib" yang harus dipahami secara bersama-sama. ${ }^{31}$

Ketiga istilah ini mengandung makna yang mendalam menyangkut manusia dan masyarakat serta lingkungan yang dalam hubungannya dengan Tuhan saling berkaitan satu sama lain. Istilah-istilah itu pula sekaligus menjelaskan ruang lingkup pendidikan islam: informal, formal dan non formal. Jamli Sahrodi menyatakan bahwa pendidikan dalam perspektif Islam merupakan propes pewarisan atau usaha muslim dalam mewariskan pengalaman, ajaran, dogma dan tradisi kepada generasi berikutnya. ${ }^{32}$ Oleh karena itu, pendidikan dikalangan dunia Islam tidak terbatas pada mempelajari teks-teks agama, melainkan juga pada tradisi, pandangan dan praktik-praktik transformasi pengetahuan serta cara mewariskan pengetahuan, ilmu dan keyakinan. Lebih eksplisit, dalam buku berjudul IImu Pendidikan Islam, M. Arifin mengungkapkan sesungguhnya pendidikan Islam dapat dipahami sebagai system pendidikan yang dapat memberikan kemampuan kepada seseorang untuk memimpin kehidupannya sesuai dengan cita-

${ }^{30} \mathrm{La}$ Ode Sismono, Di Belantara Pendidikan Bermoral, (Yogyakarta: UNY Press, 2006), h. 15

${ }^{31}$ Abdul Majid dan Juyuf Mudzakkir, Ilmu Pendidikan islam, (Jakarta: Kencana Prenada Media, 2006), h. 10

${ }^{32}$ Jamali Sahroni, Filsafat Pendidikan Islam, (Bandung: Arfini Raya, 2008), h. 20 cita dan nilai-nilai islam yang telah menjiwai dan mewarnai kepribadiannya. ${ }^{33}$

Dari definisi dan pengertian itu ada tiga unsur yang membentuk pendidikan yaitu adanya proses, kandungan, dan penerima. Kemudian disimpulkan lebih lanjut "Sesutu yang secara bertahap ditanamkan ke dalam diri manusia". Jadi definisi pendidikan islam adalah pengenalan dan pengakuan yang secara berangsur-berangsur ditanamkan ke dalam diri manusia, tentang tempat-tempat yang tepat dari segala sesuatu di dalam tatanan penciptaan, sehingga membimbing kearah pengenalan dan pengakuan tempat Tuhan yang didalam tatanan wujud dan kepribadi. Dari segi bahasa pendidikan dapat diartian perbuatan (hal, cara, dan sebagainya) mendidik, dan berarti pula pengetahuan tentang mendidik, atau memelihara (latihanlatihan dan sebagainya) badan, batin, dan sebagainya. ${ }^{34}$ Sedangkan Ihsan mengatakan bahwa pendidikan merupakan usaha untuk menumbuhkan dan mengembangkan potensipotensi pembawaan baik dalam masyarakat dan kebudayaan. Atau dengan kata lain bahwa pendidikan dapat diartikan sebagai suatu hasil peradaban bangsa yang dikembangkan atas dasar pandangan hidup bangsa itu sendiri (nilai dan norma masyarakat) yang berfungsi sebagai filsafat pendidikannya atau sebagai cita-cita dan penyataan tujuan pendidikannya. $^{35}$

Syariat Islam tidak akan dihayati dan diamalkan orang kalau hanya diajarkan saja, tetapi harus dididik melalui pendidikan Nabi sesuai ajaran Islam dengan berbagai metode dan pendekatan dari suatu segi kita lihat bahwa pendidikan islam itu lebih banyak ditunjukan kepada perbaikan sikap mental yang akan terwujud dalam amal perbuatan baik bagi keperluan diri sendiri maupun orag

${ }^{33}$ M. Arifin, Ilmu Pendidikan Islam, (Jakarta: Bumi Aksara, 2003), h. 7

${ }^{34}$ Abudin Nata, Metodologi Studi Islam, (Jakarta: Rajawali pers, 2013), h. 333

${ }^{35}$ Ahmad Tafsir, Ilmu pendidikan dalam pespektifislam, (Bandung: PT. Remaja Rosdakarya, 2005), h. 1 
lain. Dari segi lainnya, pendidikan Islam tidak bersifat teoritis saja, tetapi juga praktis. Ajaran Islam tidak memisahkan antara iman dan amal sholeh. Oleh karena itu, pendidikan Islam adalah sekaligus pendidikan iman dan pendidikan amal dan juga karena ajaran Islam berisi tentang ajaran sikap dan tingkah laku pribadi masyarakat menuju kesejahteraan hidup perorangan dan bersama. Maka pendidikan Islam adalah pendidikan individu dan pendidikan masyarakat. Semula yang bertugas mendidik adalah para nabi dan Rasul selanjutnya para ulama, dan cerdik tugas pandailah sebagai penerus tugas, dan kewajiban mereka. ${ }^{36}$ Pendidikan agama Islam merupakan kurikulum pokok yang harus dilaksanakan dengan sadar dan terencana. Karena itu optimalkan pelaksanaan pendidikan agama di sekolah umum sangat bergantung dari kesiapan PAI dalam menyelenggarakan kegiatan belajar mengajar di sekolah. Menurut Muhaimin di dalam masyarakat yang plural dibutuhkan ikatan keadapan (bound of civility), yaitu pergaulan antara lain yang diikat dengan civility (keadapan). Ikatan ini pada dasarnya dapat dibangun dari nilai-nilai universal ajaran agama, karena itu bagaimana guru agama, terutama guru PAI mampu membelajarkan agama yang difungsikan sebagai panduan moral dalam kehidupan masyarakat yang plural tersebut, dan bagaimana guru agama mampu mengangkat dimensi-dimensi konseptual dan substansial dari ajaran agama, seperti kejujuran, keadilan, kebersamaan, kesadaran, akan hak dan kewajiban dan sebagainya, untuk diaktualisasikan dan direalisasikan dalam kehidupan masyarakat tersebut.

Kesiapan guru PAI di dalam masyarakat yang plural juga menegaskan bahwa seorang guru hendaknya mampu untuk hidup mendengarkan dan menghargai pandangan dan pendapat orang lain. Walaupun cara pandang siswa dengan guru

${ }^{36}$ Zakiah Drajat, Ilmu Pendidikan Islam, (Jakarta: Bumi Aksara, 2012), h. 25-28 berbeda tentang pemahaman akidah misalnya,hal tersebut harus tetap dihargai, sudah semestinya proses pembelajaran hendaknya berlangsung secara dialogis. Artinya di dalam proses pembelajaran, guru juga harus memotivasi siswa untuk terlibat secara aktif dalam pembelajaran. Dengan demikian, dapat dikemukakan bahwa PAI adalah sebuah usaha yang sadar dan terencana yang memerlukan kesiapan matang dari guru karena PAl adalah sebuah bentuk pembelajaran di mana bahan yang dipelajari selalu lekat dengan perubahan-perubahan dalam masyarakat.

Dengan semua teori dan penjelasan yang telah diuraikan maka penulis mengambil kesimpulan Pendidikan Agama Islam adalah usaha berupa bimbingan, baik jasmani maupun rohani kepada anak didik menurut ajaran Islam, agar kelas dapat berguna menjadi pedoman hidupnya untuk mencapai kebahagiaan hidup dunia dan akhirat.

\section{Metodologi Penelitian}

\section{Metode Penelitian Yang Dipilih}

Metode penelitian yang dipilih dalam penelitian ini adalah metode penelitian kualitatif atau dikenal penelitian naturalistik (Guba dan Lincoln). ${ }^{37}$ Penelitian kualitatif merupakan prosedur penelitian yang menghasilkan data deskriptif melalui pengungkapan kata-kata tertulis atau lisan dari orang-orang, peristiwa tertentu, secara rinci dan mendalam serta perilaku yang dapat diamati. $^{38}$ Menurut John W. Creswell, dalam peneliti kualitatif, peneliti merupakan instrumen utama dalam upaya memahami makna perilakunya (behaviour meaning) dari interaksi antar objek penelitian, membaca mimik, menyelami

${ }^{37}$ Lexy J. Moleong, Metodologi Penelitian Kualitatif, (Bandung: PT. Remaja Rosdakarya, 1998), cet. ke 9, h. 15.

${ }^{38}$ C.R. Bogdan and S.J. Taylor, Introduction In Qualitative Researsh Methods, (New York: John Wiley \& Son Inc, 1993) h. 54 
perasaan, dan nilai yang terkandung dalam ucapan atau perbuatan informan atau responden. $^{39}$ Posisi peneliti dalam penelitian kualitatif, menurut Moleong, ${ }^{40}$ adalah perencana, pengumpul data, penafsir data, dan akhirnya sebagai pelapor hasil penelitiannya.

Bogdan dan Biklen ${ }^{41}$ memberikan penjelasan tentang karakteristik dari penelitian kualitatif sebagai berikut; a) Penelitian kualitatif dilakukan pada latar alamiah sebagai sumber langsung dan peneliti merupakan instrumen kunci; b) Bersifat deskriptif, yaitu menggambarkan situasi tertentu atau data yang dikumpulkan, berbentuk kata-kata atau gambar-gambar daripada angka-angka; c) Lebih memperhatikan proses dari pada hasil atau produk semata; d) Dalam menganalisa data cenderung secara induktif; dan e) Makna merupakan hal yang esensial bagi penelitian kualitatif. ${ }^{42}$

Dalam proses penelitian ini, ada beberapa karakteristik penelitian kualitatif. Pertama, peneliti telah mengadakan penelitian pendahuluan melalui pengamatan wawancara tak berstruktur dan atau studi dokumentasi. Dipersyaratkan peneliti telah mempunyai pengetahuan dasar sehingga memungkinkan untuk mengembangkan pertanyaan untuk wawancara mendalam (depth interview). Peneliti menjadi "instrumen" yang dapat memahami makna

${ }^{39}$ John W. Creswell, Educational Research, op.cit.h. 389 .

${ }^{40}$ Lexy J. Moleong, op.cit., h. 121. Lihat juga Noeng Muhadjir, Metodologi Penelitian Kualitatif, (Yogyakarta: Rake Sarasin, 1996), Edisi III, h.120.

${ }^{41}$ C.R. Bogdan and S.K. Biklen, Quantitative Research for Education: An Introduction to Theory and Methods, terj. Munandir, (Jakarta: Direktorat Jenderal Pendidikan Tinggi Departemen Pendidikan dan Kebudayaan, 1990), h. 121.

${ }^{42}$ Sugiyono, Memahami Penelitian Kualitatif, (Bandung: Simbiosa, 2009), h. 1 pengalaman terdalam (depth experience meaning) dari interaksi antar objek penelitian, membaca fenomena, menyelami perasaan, dan nilai yang terkandung dalam ucapan atau perbuatan informan atau responden. ${ }^{43}$

Kedua, peneliti berkomunikasi dengan subjek penelitian menggunakan bahasa informan, agar memungkinkan komunikasi lebih akrab dan terbuka, serta memahami latar belakang budaya informan. Ia juga dipersyaratkan memahami berbagai term (peristilahan) yang dipakai dalam acuan normatif (agama, hukum, sosial, dan budaya) dan tradisi, sehingga rapport (kesepahaman) antara peneliti dan yang diteliti dapat terjalin baik. $^{44}$

Ketiga, peneliti mengumpulkan dan mencatat data secara terperinci mengenai hal-hal yang berkaitan dengan permasalahan yang sedang diteliti. Data dipandang sebagai satuan-satuan yang saling terhubung (related), keseluruhan (unity), dan terstruktur (structured). Data (informasi) dari satu pihak di(re)cek kebenarannya dengan cara menguji keakuratan data tersebut dengan yang lainnya melalui triangulasi. Tujuannya membandingkan informasi yang diperoleh dari berbagai pihak, agar ada jaminan tingkat kepercayaan terhadap data yang diajukan. Penggunaan metode ini memungkinkan terminimalisirnya subjektivitas.

Keempat, peneliti mementingkan pandangan informan atau responden, bagaimana ia memandang dan

${ }^{43}$ Creswell, Educational Research, h. 389.

${ }^{44}$ Creswell, Educational Research, h. 394. Lihat pula beberapa kerangkan teoritis mengenai observasi dalam Isabelle Baszanger dan Nicolas Dodier, "Ethnography: Relating the Part to the Whole", dalam David Silverman (Ed.), Qualitative Research: Theory, Method, and Practice, (London, Thousand Oaks, New Delhi: Sage Publication, 2010), h. 9-34. 
menafsirkan dunia dari segi keyakinannya. Peneliti tidak memaksakan pandangannya sendiri. Peneliti memasuki wilayah penelitian tanpa generalisasi, seakan-akan tidak mengetahui sedikitpun, sehingga dapat menaruh perhatian penuh pada konsep-konsep yang dianut partisipan. ${ }^{45}$

Kelima, peneliti melakukan verifikasi, terutama jika peneliti berhadapan dengan kasus-kasus yang dipandang bertentangan (contradictive). Untuk memperoleh data yang maksimal dilihat dari validitas dan tingkat akurasinya, peneliti mencari kasus-kasus yang berbeda atau bertentangan dengan yang telah ditemukan atau melakukan uji negatif. Maksudnya, untuk memperoleh hasil yang lebih tinggi tingkat kepercayaannya yang mencakup situasi yang lebih luas, sehingga apa yang semula tampaknya berlawanan akhirnya dapat meliputi dan tidak lagi mengandung aspek-aspek yang tidak sesuai.

2. Pendekatan Penelitian: Cross-Sectional Survey Design

Pemilihan penelitian kualitatif ini berkaitan erat dengan sifat unik dari realitas sosial dan dunia aktivitas yang ada pada program Emotional Spiritual Achievement (ESA), sebagai salah satu program pendidikan dan sosial keagamaan yang memiliki keunggulan kelembagaan dan peran di masyarakat Indonesia. Keunikannya bersumber dari pelatihanpelatihan yang telah dilaksanakan. Berbagai aktivitasnya bersifat unik dan penuh motivasi, baik sebagai makhluk psikis, sosial, dan budaya, yang mengaitkan makna dan interpretasi dalam bersikap dan bertingkah laku. Makna dan interpretasi itu sendiri dipengaruhi oleh lingkungan sosial dan budaya. Kompleksitas sistem makna tersebut secara konstan digunakan oleh seseorang

\footnotetext{
${ }^{45}$ John W. Creswell, Qualitative Inquiry and Research Design, h. 202.
}

dalam mengorganisasikan sikap dan tingkah lakunya sehari-hari. ${ }^{46}$ Pola perilaku dan pemaknaannya tersebut dapat diamati secara fenomenologis ${ }^{47}$ dan dipahami melalui pengamatan terlibat. ${ }^{48}$

Untuk mencapai tujuan tersebut, pendekatan $^{49}$ yang digunakan dalam penelitian ini adalah cross-sectional survey design, yakni study at one point through data-cross-secational in short time. ${ }^{50}$ Pendekatan ini dipilih karena memfokuskan studi pada satu fokus dan lokus tertentu, yakni Urgensi Program Emotional Spiritual Achievement (ESA) dalam membentuk pola pikir siswa pada mata pelajran (PAI) di SMAN 7 dan SMKN 1 Kota Tangerang Selatan, dengan

\footnotetext{
${ }^{46}$ John W. Creswell, Educational Research, h. 45-47; John W. Creswell, Qualitative \& Quantitative Approaches, h. 42-45.

${ }^{47}$ Melalui paradigma fenomenologis, penelitian berusaha memahami arti peristiwa dan kaitan-kaitannya (pola hubungan) terhadap sesuatu dalam situasi-situasi tertentu. Fenomenologis sangat dipengaruhi oleh Edmund Husserl danAlfred Schultz, pengaruh lainnya berasal dari Max Weber yang memberi tekananpada pengertian interpretatif terhadap pemahaman manusia (verstehen). Lexy J. Moleong, Metodologi Penelitian kualitatif, (Bandung: Rosdakarya, 2004), h. 8-9.

${ }^{48}$ Pengamatan terlibat merupakan penciri penelitian kualitatif, yang mencirikan pendekatan, metodologi, serta pada teknis analisis "emik", untuk objek-spesifiknya menggunakan "teknik analisis kualitatif logik-verbal melalui pencarian esensial". Noeng Muhadjir, Metodologi Penelitian, (Yogyakarta: Rakesarasin, 1999), h. 89.

${ }^{49}$ Dalam kamus Bahasa Indonesia "metode" dimaknai sebagai cara yang teratur dan berfikir baik untuk mencapai maksud. Sehingga dapat dipahami bahwa metode berarti suatu cara yang harus dilalui untuk menyajikan bahan pelajaran agar mencapai tujuan pelajaran. Departeman Pendidikan Dan Kebudayaan, Kamus Besar Bahasa Indonesia, (Jakarta: Balai Pustaka, 1995), h. 52

${ }^{50}$ John W. Creswell, Educational Research, h. 389 dan 393. Lihat juga Noeng Muhajir, Metode Penelitian Kualitatif, (Yogyakarta: Rakesarasin, 1998), edisi ke-3, cet. ke-8, h. 21.
} 
melibatkan banyak informan. Pada operasionalnya penelitian ini melakukan observasi partisipatif (partisipative observation), dan menggunakan wawancara bebas dengan pedoman terhadap lebih dari 20 informan. Sebagian data diperoleh melalui pengamatan sebagai alat pengumpul data yang pokok dan bertujuan menguji asumsi pada fokus penelitian. Konsekuensi dari metode ini adalah diperlukannya variabel-variabel dasar, yang indikator-indikatornya itu menunjuk pada keragaman data yang memadai. Selain itu, penelitian ini akan menggunakan pendekatan etnografi. menemukan dan menggambarkan organisasi pikiran yang ada dan hidup pada sebuah lingkungan masyarakat, apakah masyarakat itu tradisional, urban, modern atau masyarakat multikultural. ${ }^{51}$

Etnografi dipilih sebagai pendekatan untuk menelaah dan meneliti "Program Emotional Spiritual Achievement (ESA) yang dilaksankan di SMAN 7 dan SMKN 1 Kota Tangerang Selatan. Pemilihan metode etnografi, penulis pandang sangat relevan, antara lain: pertama, karena Program Emotional Spiritual Achievement (ESA) yang dilaksankan di SMAN 7 dan SMKN 1 Kota Tangerang Selatan bersifat unik, baik dari segi gagasan maupun dari segi pelaksanaan sistem pendidikannya. Kedua, belajar bersama dan berkumpulnya Pendidik, Tenaga Kependidikan dan Peserta Didik dalam suatu Program Emotional Spiritual Achievement (ESA) di dalam sebuah ruangan, dalam jangka waktu tiga hari telah melahirkan sistem nilai dan pola pikir dan perilaku tertentu yang khas dan menjadi identitas serta bisa dijadikan rujukan oleh seluruh sivitas akademika.

Selanjutnya identitas yang khas beserta seluruh sistem nilai dan makna tersebut diwariskan kepada anggota- anggota baru yang datang setiap tahun. Sistem nilai, perilaku dan identitas yang khas tersebut merupakan hasil karya bersama yang secara terus menerus disempurnakan. Sistem nilai tadi akhirnya membentuk suatu budaya dan pola pikir yang unik dan khas, yang berbeda dengan budaya, pola pikir masyarakat lingkungan sekitarnya.

\section{Data dan Sumber Data}

1. Data

Data yang hendak diperoleh dari penelitian ini ada dua macam, yaitu data primer dan data sekunder. Data primer diperoleh melalui observasi dan wawancara dalam penelitian ini, terkait dengan hal-hal sebagai berikut:

i. Kegiatan-kegiatan dan implementasi Program Emotional Spiritual Achievement (ESA) yang dilaksankan di SMAN 7 dan SMKN 1 Kota Tangerang Selatan, baik menyangkut tujuan, SDM, kurikulum dan pembelajaran, fasilitas, dan kelembagaan;

ii. Faktor kelebihan dan kelemahan dalam pelaksanaan Program Emotional Spiritual Achievement (ESA) yang dilaksankan di SMAN 7 dan SMKN 1 Kota Tangerang Selatan;

iii. Peran guru PAl dalam implementasi Program Emotional Spiritual Achievement (ESA) yang dilaksankan di SMAN 7 dan SMKN 1 Kota Tangerang Selatan yang dapat dikembangkan dan dijadikan alternatif panduan untuk pembukaan, pengembangan, dan pemertahanan Program Emotional Spiritual Achievement (ESA) selanjutnya.

Sedangkan data sekunder diperoleh melalui studi dokumentasi dan kepustakaan, terkait dengan permasalahan penelitian tersebut, baik bersumber dari hasil-hasil penelitian sebelumnya, media massa, maupun sumber-sumber lain yang relevan.

\footnotetext{
${ }^{51}$ Amri Mazali, op.cit., h. xvi-xx.
} 


\section{Sumber Data}

Sumber data terdiri dari data primer dan data sekunder. Sumber data primer adalah yang terdiri dari:
a. Kepala sekolah;
b. Pendidik (guru);
c. Peserta Didik;
d. Tenaga Kependidikan;

Sumber data primer tersebut di atas dipilih karena pertimbangan-pertimbangan sebagai berikut:

a. Memiliki pengetahuan yang cukup banyak tentang masalah yang diteliti;

b. Menguasai secara baik masalah yang diteliti;

c. Terlibat secara langsung dengan obyek penelitian;

d. Mudah ditemui karena setiap hari di tempat penelitian.

Sedangkan sumber data sekunder, penulis peroleh dari buku-buku, jurnal, hasil penelitian, artikel, surat kabar, internet, dan sumber-sumber lain yang relevan serta menunjang terhadap penelitian ini.

\section{Teknik dan Prosedur Pengumpulan Data}

1. Teknik Pengumpulan Data

$$
\text { Sugiyono berpendapat bahwa }
$$

dalam penelitian kualitatif teknik pengumpulan data dapat dilakukan secara triangulasi (gabungan), analisis data bersifat induktif, dan hasil penelitian lebih menekankan makna dari pada generalisasi. ${ }^{52}$ Untuk mendapatkan data penelitian, sesuai dengan metode yang dipakai, maka pengumpulan data dilakukan dengan menggunakan beberapa teknik, yaitu: observasi, teknik wawancara mendalam, dan dokumentasi. Ketiga teknik tersebut digunakan secara berulangulang dan bergantian sesuai dengan

\footnotetext{
${ }^{52}$ Sugiyono, op.cit., h. 1. Dalam penelitian kualitatif, sering digunakan istilah transferability sebagai ekuivalen dari istilah generalisasi, lihat Sugiyono, Memahami Penelitian Kualitatif, h. 3.
}

keperluan pada saat penelitian dilakukan dan akan dijelaskan sebagai berikut:

a. Observasi

Observasi $^{53}$ atau pengamatan merupakan salah satu teknik penelitian yang digunakan dalam penelitian ini. Terlepas dari jenis pengamatan, dapat dikatakan bahwa pengamatan terbatas dan tergantung pada jenis dan variasi pendekatan.

Observasi digunakan dalam penelitian ini berdasarkan pada beberapa pertimbangan, seperti yang dikemukakan oleh Jorgensen, ${ }^{54}$ yakni:

i. Minat khusus pada makna dan interaksi antara sivitas akademika SMAN 7 dan SMKN1 Kota Tangerang Selatan berdasarkan perspektif sivitas akademika tersebut selaku orang dalam, pada situasi atau keadaan tertentu;

ii. Fondasi dan metode dari penelitian ini adalah kedisinian dan kekinian dalam kehidupan sehari-hari sivitas akademika SMAN 7 dan SMKN 1 Kota Tangerang Selatan;

iii. Bentuk teori dan penteorian yang menekankan interpretasi dan pemahaman eksistensi manusia yang dipersepsi dan dilakukan oleh sivitas akdemika SMAN 7 dan SMKN 1 Kota Tangerang Selatan;

iv. Logika dan proses penelitian ini bersifat terbuka, luwes, opportunistic, dan menuntut pemahaman (verstehen) terhadap berbagai fenomena dan problematika yang ada pada Program

${ }^{53}$ Menurut Arikunto teknik observasi digunakan untuk mengamati secara langsung dan tidak langsung tentang perilaku personel sekolah terutama kepala sekolah yang terkait dengan kinerja dan kompetensi jabatannya. Suharsimi Arikunto. Prosedur Penelitian, (Yogyakarta: Rineka Cipta, 1990), h. 229. Lihat pula dalam R. Murray Thomas, Blending Qualitative and Quantitative Research Methods in Thesis and Dissertations, h. 242.

${ }^{54}$ Deddy Mulyana, Metodologi Penelitian Kualitatif, (Bandung: PT Remaja Rosdakarya, 2004), h. 164. 
Emotional Spiritual Achievement di SMAN

7 dan SMKN 1 Kota Tangerang Selatan;

v. Berbagai data yang diperoleh didasarkan pada fakta yang diperoleh dalam situasi nyata pada Program Emotional Spiritual Achievement di SMAN 7 dan SMKN 1 Kota Tangerang Selatan melalui berbagai pendekatan dan rancangan yang mendalam, kualitatif, dan studi kasus;

vi. Penerapan peran partisipan (sivitas akademika SMAN 7 dan SMKN 1 Kota Tangerang Selatan) yang menuntut hubungan langsung antara peneliti dengan sivitas akademika SMAN 7 dan SMKN 1 Kota Tangerang Selatan (sebagai pribumi lapangan).

b. Wawancara Mendalam

Wawancara menjadi cara pengumpulan data yang terpenting dalam penelitian ini, dengan tujuan untuk mengetahui pendapat, persepsi, perasaan, pengetahuan, pengalaman dan penginderaan sivitas akademika SMAN 7 dan SMKN 1 Kota Tangerang Selatan dan lainnya mengenai berbagai permasalahan dalam penelitian ini. ${ }^{55}$ Dalam hal ini, peneliti mengambil beberapa informan di SMAN 7 dan SMKN 1 Kota Tangerang Selatan baik pimpinan, guru, peserta didik (siswa/santri), tenaga kependidikan. Wawancara dilakukan secara bebas dengan pedoman yang telah dipersiapkan sebelumnya. ${ }^{56}$

Untuk memudahkan penerapan wawancara di lapangan, maka alur wawancara yang dilakukan peneliti adalah sebagai berikut:

${ }^{55}$ Wawancara adalah percakapan dengan maksud tertentu yang dilakukan oleh dua pihak, yaitu pewawancara (interviewer) yang mengajukan pertanyaan, dan yang diwawancarai (interview) yang memberikan jawaban atas pertanyaan itu. Lexy J. Moleong, op.cit., h. 135.

${ }^{56}$ Teknik ini dikenal juga dengan istilah cross-sectionalsurvey design. LihatJohn W. Creswell, Educational Research..., op.cit., h. 389 dan 393. a. Menetapkan informan utama (key informan), yakni pimpinan, guru, peserta didik, tenaga kependidikan;

b. Menyiapkan pokok-pokok permasalahan yang menjadi bahan wawancara;

c. Membuka alur wawancara dengan memperkenalkan diri dan menjelaskan pokok-pokok wawancara;

d. Melakukan wawancara sebagai pokok kegiatan, terkait dengan pokok pembicaraan dan penelusuran lebih dalam pada hal-hal teknis;

e. Merekam wawancara dan menuliskannya sebagai bagian catatan lapangan untuk menghasilkan "catatan tebal" (thick description);

f. Mengkonfirmasi hasil wawancara;

g. Menindaklanjuti hasil wawancara yang telah diperoleh.

Dalam teknik wawancara ini, penulis juga menggunakan pedoman wawancara $^{57}$ dan menggunakan slip, ${ }^{58}$ serta dibantu dengan voice recorder agar materi wawancara dapat direkam secara utuh dan lengkap. Peneliti mengadakan komunikasi dengan subjek penelitian memakai bahasa dari informan (atau responden) yang memungkinkan komunikasi lebih akrab dan terbuka, memahami latar belakang budaya informan (atau responden) dan juga memahami peristilahan yang dipakai dalam agama Islam dan tradisi, sehingga rapport antara peneliti dan yang diteliti dapat terjalin baik. $^{59}$

\footnotetext{
${ }^{57}$ Pedoman wawancara dimaksudkan untuk mengarahkan dan mempermudah penulis mengingat pokok-pokok permasalahan yang diwawancarakan dengan sumber data utama (interview). Lihat Masri Singarimbun, Metode Penelitian Survai, (Jakarta : LP3ES, 1989), h. 10.

${ }^{58}$ Slip adalah potongan atau carik kertas (semacam kartu kutipan) yang khusus digunakan untuk mencatat hasil wawancara. Lihat Masri Singarimbun, Metode Penelitian Survai, (Jakarta: LP3ES, 1989), h. 10.

${ }^{59}$ John W. Creswell, Educational Research..., op.cit.,h. 394.
} 


\section{c. Dokumentasi}

Teknik cukup penting yang juga digunakan dalam penelitian ini adalah teknik dokumentasi. ${ }^{60}$ Dalam teknik dokumentasi, peneliti mengecek dokumendokumen yang ada di SMAN 7 dan SMKN 1 Kota Tangerang Selatan, berupa panduan pembelajaran, laporan-laporan, dan foto. Pada tahapan selanjutnya, peneliti juga melakukan pelacakan terkait kajian-kajian teori yang berkaitan dengan masalah yang diteliti. Teori-teori tersebut digunakan dalam analisis pembahasan dari berbagai deskripsi dan temuan yang dihasilkan.

2. Tahapan Penelitian

Dalam penelitian ini, tahap-tahap pengumpulan data penelitian meliputi tiga tahapan, yaitu: tahap orientasi, tahap eksplorasi dan tahap member check.

Tahap orientasi. Dalam tahap ini, peneliti melakukan pra-observasi ke SMAN 7 dan SMKN 1 Kota Tangerang Selatan sebagai lokasi penelitian yang akan diteliti. Pra-observasi dilakukan di SMAN 7 dan SMKN 1 Kota Tangerang Selatan dengan cara wawancara dengan sivitas akademika SMAN 7 dan SMKN 1 Kota Tangerang Selatan, yakni pimpinan, guru, tenaga kependidikan, peserta didik. Kemudian peneliti juga melakukan studi dokumentasi serta kepustakaan untuk melihat dan mencatat data-data yang diperlukan dalam penelitian ini.

Tahap eksplorasi. Tahap ini merupakan tahap pengumpulan data pada SMAN 7 dan SMKN 1 Kota Tangerang

\footnotetext{
${ }^{60}$ Menurut Suharsimi Arikunto, metode ini dimaksudkan untuk mencari data mengenai hal-hal atau variable, baik berupa catatan, transkrip, buku, surat kabar, majalah, prasasti, notulen rapat, legger, agenda, dan lain sebagainya. Dibandingkan dengan teknik lain, maka teknik dokumentasi relatif tidak begitu sulit, dalam arti apabila ada kekeliruan, sumber datanya masih tetap dan belum berubah. Suharsimi Arikunto, Prosedur Penelitian suatu Pendekatan Praktek, (Jakarta: PT. Rineka Cipta, 2002), cet. ke 5, h. 206.
}

Selatan yang dijadikan lokus penelitian. Penelitian dilakukan melalui wawancara dengan unsur-unsur yang terkait, dengan pedoman wawancara yang telah disediakan peneliti, dan melakukan observasi langsung maupun tidak langsung tentang kondisi SMAN 7 dan SMKN 1 Kota Tangerang Selatan serta mengadakan pengamatan langsung tentang Program Emotional Spiritual Achievement (ESA) di SMAN 7 dan SMKN 1 Kota Tangerang Selatan.

Tahap member check. Setelah data diperoleh di SMAN 7 dan SMKN 1 Kota Tangerang Selatan, baik melalui observasi, wawancara ataupun studi dokumentasi, selanjutnya informan mengisi data yang diperlukan. Informan diberi kesempatan untuk menilai data dan informasi yang telah diberikan kepada peneliti. Informan dipersilakan untuk melengkapi atau merevisi data dan dapat memberikan data baru, selanjutnya data yang ada tersebut diangkat dan dilakukan authenticcheck yaitu mengecek keabsahan data sesuai dengan sumber aslinya.

2. Teknik Analisis Data

1. Pengolahan Data

Di dalam pengolahan data, yang pertama kali dilakukan adalah mengecek kelengkapan data sesuai dengan fokus penelitian. Data yang terkumpul berupa hasil wawancara, catatan lapangan, gambar, foto, dokumen, biografi, artikel, karya-karya ilmiah, buku-buku dan lain sebagainya yang berkaitan dengan yang diteliti, diatur dan dikelompokkan. Setelah itu diuraikan dalam bentuk deskriptif dan selanjutnya dianalisis sesuai dengan pendekatan yang dipakai dalam penelitian ini.

Sebelum dianalisis, dilakukan pemeriksaan keabsahan data. Untuk menguji keabsahan dan validitas data, peneliti mencocokkan dan membandingkan data dari berbagai sumber, baik sumber lisan (hasil 
wawancara), sumber tulisan (pustaka), maupun data hasil observasi. Secara sederhana pengujian keabsahan data dilakukan dengan teknik-teknik triangulasi, perpanjangan kehadiran, pengamatan secara terus menerus, pengecekan kecukupan referensi, dan analisis kasus negatif. ${ }^{61}$ Teknik triangulasi adalah teknik untuk pemeriksaan validitas data dengan memanfaatkan sumber lain sebagai bahan perbandingan. Triangulasi dengan sumber lain berarti mengecek validitas data dengan alat dan waktu yang berbeda. Sebagai contoh, data hasil dokumentasi dibandingkan dengan data hasil wawancara. Membandingkan apa yang dikatakan di depan umum dengan apa yang dikatakan secara pribadi. Membandingkan apa yang dikatakan orang dengan apa yang diamati, dan lain sebagainya. ${ }^{62}$

Peneliti selaku instrumen pengumpul data, kehadiran dan keikutsertaannya dalam pengamatan suatu objek penelitian, tentu tidak dapat dilakukan dalam kurun waktu yang sangat singkat, sehingga diperlukan teknik perpanjangan kehadiran. Perpanjangan kehadiran akan lebih memungkinkan peningkatan derajat validitas data yang dikumpulkan. Dengan cara ini, peneliti akan lebih akrab dengan responden dan berpeluang untuk lebih dapat memahami tradisi dan budaya yang mengitarinya. Hasilnya diharapkan, data yang digali akan menjadi semakin akurat.

Teknik lainnya yaitu pengamatan secara terus menerus. Teknik ini menghendaki ketekunan peneliti dalam mengamati suatu objek penelitian. Berbeda dengan cara di atas, bila perpanjangan kehadiran menghasilkan keluasan lingkup data yang dikumpulkan, maka pengamatan secara terus menerus

${ }^{61}$ Y.B. Lincoln and E.G. Guba,Naturalistic Inquiry, (California: Beverly Hills, 1985),h. 140.

${ }^{62}$ Lexy J. Moleong, op.cit., h. 178. akan menghasilkan kedalaman data yang dicari. Selanjutnya adalah teknik pengecekan kecukupan referensi. Teknik ini dilakukan dengan memanfaatkan berbagai sumber atau media yang tersedia, seperti rekaman tape recorder dan fotofoto untuk diperbandingkan dengan catatan hasil wawancara. Penggunaan teknik demikian akan memudahkan peneliti sewaktu mengadakan analisis dan penafsiran data.

Di samping teknik di atas, pengecekan keabsahan data juga dilakukan dengan cara analisis kasus negatif. Caranya adalah dengan mengumpulkan kasus-kasus yang bertolak belakang dengan informasi yang diperoleh. Dengan membandingkan informasi dan data yang diperoleh dengan kasus-kasus yang bertolak belakang, diharapkan dapat memperjelas analisis yang dianggap lebih terpercaya. Berbagai teknik yang telah diuraikan di atas akan menghasilkan data penelitian yang akurat, luas, dan mendalam.

2. Analisis Data

Menurut Patton, teknik analisis data adalah proses kategori urutan data, mengorganisasikannya ke dalam suatu pola, kategori, dan satuan uraian dasar. Ia membedakannya dengan penafsiran, yaitu memberikan arti yang signifikan terhadap analisis, menjelaskan pola uraian, dan mencari hubungan di antara dimensidimensi uraian. ${ }^{63}$

Analisis data dimulai dengan menelaah seluruh data tentang Program Emotional Spiritual Achievement (ESA) yang tersedia dari berbagai sumber, yaitu wawancara, pengamatan yang sudah dituliskan dalam catatan lapangan, dokumen pribadi, dokumen resmi, gambar, foto, dan sebagainya. Setelah dibaca, dipelajari, dan ditelaah, langkah berikutnya ialah mengadakan reduksi data

${ }^{63}$ Ibid, h. 280 
yang dilakukan dengan jalan membuat rangkuman inti. Langkah selanjutnya adalah menyusunnya dalam satuan-satuan. Satuan-satuan itu dikategorisasikan pada langkah berikutnya. Kategori-kategori itu dibuat sambil melakukan koding. Tahap akhir dari analisis data ini adalah mengadakan pemeriksaan keabsahan data. Setelah tahap ini, mulailah kini tahap penafsiran data dalam mengolah hasil sementara menjadi teori substantif dengan menggunakan metode tertentu. ${ }^{64}$ Tahapannya adalah sebagai berikut.

i. Reduksi Data; Reduksi data merupakan kegiatan merangkum catatan-catatan lapangan tentang Program Emotional Spiritual Achievement (ESA) dengan memilah hal-hal pokok yang berhubungan dengan permasalahan penelitian. Rangkuman catatan-catatan lapangan itu kemudian disusun secara sistematis agar memberikan gambaran yang lebih tajam serta mempermudah pelacakan kembali apabila sewaktuwaktu data tersebut diperlukan kembali.

ii. Display Data; Display data berguna untuk melihat gambaran keseluruhan hasil penelitian tentang Program Emotional Spiritual Achievement (ESA), baik yang berbentuk matriks ataupun pengkodean. Berdasarkan hasil reduksi data dan display data itulah, selanjutnya peneliti dapat menarik kesimpulan data, memverifikasikan data tersebut sehingga menjadi kebermaknaan data.

iii. Keabsahan Data; Dalam menguji keabsahan data, peneliti menggunakan teknik trianggulasi. Trianggulasi adalah teknik pemeriksaan keabsahan data yang memanfaatkan sesuatu yang lain, di luar data untuk keperluan pengecekan atau sebagai pembanding terhadap data itu. Teknik trianggulasi

${ }^{64}$ Ibid, h. 247. yang paling banyak digunakan ialah pemeriksaan melalui sumber lainnya. ${ }^{65}$

iv. Kesimpulan; Kesimpulan juga dimaksudkan untuk menarik "benang merah", agar dapat dijadikan transferability, yakni hasil penelitian tentang Program Emotional Spiritual Achievement (ESA) dapat digunakan di tempat lain, manakala tempat tersebut memiliki karakteristik yang tidak jauh berbeda. Transferability sebanding dengan istilah generalisasi dalam penelitian kuantitatif. ${ }^{66}$

3. Validitas Data

Untuk meminimalisir pseudo data atau subjektivitas, maka terdapat beberapa langkah untuk menjaga keabsahan data. Teknik pemeriksaan data dalam penelitian ini dilaksanakan berdasarkan kriteria tertentu, yang dibagi pada empat kriteria yang digunakan untuk melakukan pemeriksaan keabsahan data kualitatif, sebagai berikut.

i. Derajat Kepercayaan (credibility); Kredibilitas ini merupakan konsep pengganti dari konsep validitas internal dalam penelitian kualitatif. Kriteria kredibilitas ini berfungsi untuk melakukan penelaahan data secara akurat agar tingkat kepercayaan penemuan dapat dicapai. Adapun teknik untuk menentukan kredibilitas penelitian adalah 1) memperpanjang observasi partisipatoris, 2) pengamatan yang kontinyu, 3) triangulasi, 4) membicarakannya dengan orang lain atau Focus Group Discussion (FGD), 5) menganalisis kasus negative, 6) menggunakan referensi, dan 7) mengadakan member check.

ii. Keteralihan (transferability); Konsep ini merupakan pengganti dari validitas eksternal dalam penelitian kualitatif. Validitas eksternal diperlukan untuk memperoleh generalisasi. Transferabilitas

${ }^{65}$ Lexy J. Moleong, op.cit., h. 330.

${ }^{66}$ Sugiyono, Memahami Penelitian Kualitatif, op.cit.,h. 3. 
hanya melihat "kemiripan" sebagai kemungkinan terhadap situasi-situasi yang berbeda. Teknik yang digunakan untuk transferabilitas ini dilakukan dengan uraian rinci (thick description).

iii. Kebergantungan (dependability); Konsep ini merupakan pengganti dari konsep reability dalam penelitian kualititatif. Reability tercapai bila alat ukur yang digunakan secara berulang-ulang; dan hasilnya sama. Dalam penelitian kualitatif, alat ukur bukan benda, melainkan manusia atau si peneliti itu sendiri. Teknik yang digunakan untuk mengukur kebergantungan adalah auditing, yakni pemeriksaan data yang sudah dipolakan.

iv. Kepastian (Confirmability); Konsep ini merupakan pengganti dari "objektivitas" dalam kualitatif. Dalam kualitatif, objektivitas itu diukur melalui orangnya atau penelitinya. Diakui bahwa peneliti itu memiliki pengalaman subjektif. Namun, bila pengalaman tersebut dapat disepakati oleh beberapa orang, maka pengalaman peneliti itu dapat dipandang objektif. Jadi, persoalan objektivitas dan subjektivitas dalam penelitian.

D. Hasil Penelitian Dan Pembahasan

a. Temuan Penelitian

1. Implementasi Program Emotional Spiritual Achievement (ESA) di SMAN 7 dan SMKN 1 Kota Tangerang Selatan

Program Emotional Spiritual Achievement atau yang disebut dengan ESA adalah suatu program yang teratur dilaksanakan oleh sebagian sekolah di Kota Tangerang Selatan, program ini berada di bawah naungan Yayasan Al-Kahfi yang berpusat di Kota Surabaya. Program Emotional Spiritual Achievement (ESA) dilaksanakan dua kali dalam setahun, dalam pelaksanaan program ESA ini terdapat berbagai kegiatan dari mulai pembukaan, penyampaian materi dan penutup.

Program Emotional Spiritual Achievement (ESA) adalah program pengembangan kepribadian dengan tujuan membentuk karakter insan yang islami yang memadukan kecerdasan Emosional dan kecerdaan Spiritual sehingga dapat melahirkan sebuah kehidupan yang meningkatkan keimanan terhadap Allah. Penyampaian materi menggunakan pendekatan dan sosiodrama sehingga yang mengikuti program ini bisa dapat dengan mudah diikuti. Pembukaan kegiatan Program Emotional Spiritual Achievement (ESA) dilaksanakan di aula sekolah yang dihadiri langsung oleh kepala sekolah, guru-guru dan juga dihadiri dan di dukung oleh kepala cabang Dinas Kependidikan dan Kebudayaan dari Kota Tangerang Selatan, hadir pula ketua Yayasan Al-Kahfi dan segenap panitia Program Emotional Spiritual Achievement (ESA).

Dari hasil wawancara dengan ketua panitia Program Emotional Spiritual Achievement atau ESA, program ini sangat disambut antusias dan sangat di dukung oleh kepala sekolah SMAN 7 dan SMKN 1 Kota Tangerang Selatan, dalam pelaksanaan Program Emotional Spiritual Achievement (ESA) ini dalam sehari ada dua sesi penyampaian materi yang di sampaikan oleh pemateri dari Al-Kahfi. Pelaksanaan Program Emotional Spiritual Achievement (ESA) berjalan selama dua hari yang dilaksanakan pada hari libur yakni hari sabtu dan ahad. Setelah kegiatan pembukaan, penyampaian materi dilakukan didalam kelas yang dibagi menjadi tiga forum, dibagi menjadi beberapa forum tersebut karena untuk bertujuan keefektifan dalam penyampaian materi dan lain sebagainya.

Di dalam pelaksanaan program ESA ibu Asni menyampaikan bahwa siswa dan siswi yang mengikuti program ini di bimbing dan di motivasi untuk membangkitkan ketaqwaan mereka kepada Allah SWT, meningkatkan Iman dan mengontrol emosional mereka, belajar mengelola emosi dengan baik, sehingga dapat menumbuhkan dalam diri peserta didik untuk melakukan halhal yang positif dan dapat saling melakukan 
hal kebaikan di dalam sekolah, kelas maupun diluar kelas. ${ }^{67}$

Penulis sangat mendukung berjalannya program ini di sekolah-sekolah karena dari hasil pengamatan yang penulis dapatkan program ini sangat bagus sekali, sangat membantu sekolah terutama guru pendidikan Agama Islam. Dalam program ini banyak sekali yang di dapat oleh peserta didik dalam hal keimanan, ketaqwaan dan kecintaan kepada sang kholiq Allah SWT, tidak sampai disitu siswa siswi juga banyak belajar bagaimana bermu'amalah dengan sesama teman, guru, dan lingkungan sekolah, sikap terhadap sesama. Dan semua itu sangat terasa ketika penulis pribadi pertama kali menginjakkan kaki di dua sekolah tempat penulis melakukan penelitian, sangat terasa bangaimana sikap, kehangatan siswa siswi ketika ada tamu, mereka senyum ramah, mereka menanyakan hal keperluan datang kesekolah, kesan pertama kali disekolah sangat terharu dan sangat nyaman, karena keramahan siswa siswi begitu pula para guruguru. Begitulah keadaan yang penulis alami, semua itu tidak mungkin berjalan dengan sendirinya, melainkan salah satunya sekolah SMAN 7 dan SMKN 1 Kota Tangerang telah melakukan banyak hal termasuk salah satunya aktif melaksanakan kerja sama yang di laksanakan melewati Program Emotional Spiritual Achievement (ESA).

2. Faktor kelebihan dan kelemahan dalam pelaksanaan program Emotional Spiritual Achievement (ESA) di SMAN 7 dan SMKN 1 Kota Tangerang Selatan

Setiap kegiatan maupun program yang dilaksanakan memiliki faktor kelebihan dan kelemahan tersendiri begitu pula dengan Program Emotional Spiritual Achievement (ESA) yang telah penulis teliti, diantara faktor kelebihan dan kelemahan tersebut ialah:

a. Faktor kelebihan yang ada pada Program Emotional Spiritual Achievement (ESA) adalah dapat meningkatkan keimanan

\footnotetext{
${ }^{67}$ Wawancara pribadi dengan ketua panitia pelaksana program ESA, 7 September 2019.
}

terhadap Allah, program ini memberikan pelatihan yang secara khusus kepada siswa maupun struktural yang ada di sekolah sehingga dengan adanya program ini sangat membantu dalam pendidikan keagamaan khususnya pendidikan Agama Islam yang berjalan di sekolah.

b. Faktor kekurangan yang ada pada Program Emotional Spiritual Achievement (ESA) adalah terlalu lama waktu pelaksanaannya yang memakan waktu kurang lebih 2 hari dengan beberapa sesi penyampaian materi, sehingga membuat siswa maupun siswi sebagian dari mereka ada yang tidak melanjutkan mengikuti Program Emotional Spiritual Achievement (ESA) karena memang tidak disalahkan lagi dengan beragam kepribadian peserta didik, ada yang mungkin malas terlalu lama mengikuti materi, ada juga yang memiliki acara keluarga bersama dengan keluarga, sehingga hari ke dua sebagian dari mereka tidak lagi hadir ke forum Program Emotional Spiritual Achievement (ESA). Padahal dalam materi Program Emotional Spiritual Achievement (ESA) wajib dan harus diikuti sampai selesai karena jika tidak diikuti dengan baik siswa maupun siswi di khawatirkan setengansetengah dalam memahami apa yang disampaikan oleh pemateri.

c. Dengan semua kelebihan dan kelemahan yang telah penulis paparkan, penulis memiliki saran yang mungkin dapat dijadikan masukan dan bahan evaluasi bersama, yakni sebisa mungkin waktu pelaksanaan Program Emotional Spiritual Achievement atau yang disebut ESA ini hendaknya lebih di perhatikan lagi melihat dan mengamati siswa siswi yang memang tergolong anak remaja yang masih labil, setidaknya waktu pelaksanaan ESA lebih dipersingkat dengan tidak mengurangi kualitas penyampaian materi dan lain sebagainya.

3. Peran guru PAI dalam mengembangkan kecerdasan Emotional Spiritual 
Achievement (ESA) di SMAN 7 dan SMKN

1 Kota Tangerang Selatan

Guru adalah peran utama bagi setiap anak didik, selain tugas sebagai guru dan sebagai pengajar maupun pendidik, guru juga berperan sebagai model atau contoh bagi siswa siswinya. Sebagai guru yang memiliki peranan penting dalam dunia pendidikan itu sendiri, guru harus memiliki stategi atau metode dalam pendekatan mendidik. Baik itu dengan cara membimbing, mengajar, memotivasi atau sebagai pengarah yang baik dan santun kepada siswa siswinya.

Sebagaimana yang diungkapkan oleh Saiful Djamarah, guru adalah tenaga pendidikan yang memberikan sejumlah ilmu pengetahuan kepada anak didik di sekolah, guru juga bertugas menanamkan nilai-nilai dan sikap kepada anak didik agar anak didik memiliki kepribadian yang paripurna, dengan keilmuan yang dimilikinya, guru membimbing anak didik dalam mengembangkan potensinya. ${ }^{68}$ Begitu pula dengan hasil wawancara dengan siswa siswi SMAN 7 dan SMKN 1 Kota Tangerang Selatan, bahwa peran guru PAI di sekolah sudah sangat baik, mereka mengatakan pendekatan dan bimbingan guru pada saat pembelajaran sangat baik dan mudah dipahami, begitu pula mereka sering diberikan nasehat dan diajarkan agar senantiasa saling menghormati, baik sesama teman terlebih kepada guru-guru di sekolah. Emosi ialah kecendrungan untuk bereaksi terhadap suatu perasaan atau pikiran dalam suatu kondisi (Goleman, 2006). Siswa siswi sekolah menengah yang dalah tahap perkembangannya memiliki kecendrungan emosi yang berunah-ubah, kondisi ini menjadi wajar karena remaja merupakan masa perkembangan yang mengakibatkan perunahan kognitif, dan kehidupan bersosial. Sebagaimana hasil wawancara dengan guru PAI di SMKN 1 Kota Tangerang selatan di selasela mengajar, guru menyampaikan motivasi

${ }^{68}$ Pupuh faturrahman, Strategi Belajar Mengajar Melalui Penanaman Konsep Umum dan Konsep Islami, (Bandung: PT Rafika Adita), h. 43 secara lisan maupun dalam bentuk tayangan video untuk meluruskan niat belajar karena Allah, berbakti kepada kedua orang tua dengan belajar sungguh-sungguh, serta optimis untuk menjalani kehidupan. Berbeda dengan guru PAI di SMAN 7 Kota Tangerang Selatan beliau memilih metode dengan cara membimbing secara pribadi terhadap siswa siwinya karena menurutnya dengan membimbing banyak memberikan dampak bagi siswa siswinya dalam pemahaman terhadap kecerdasan emosi maupun spiritual mereka. Semua upaya guru dalam mengembangkan emosional dan spiritual siswa siswi adalah bentuk usaha nyata yang guru lakukan, meskipun terdapat perbedaan namun semua itu dalam satu tujuan yakni ingin semua peserta didik melakukan hal-hal yang positif.

Sedangkan dalam kehidupan spiritual, aspek yang ditekankan ialah bagaimana siswa siswi sanggup memaknai tujuan hidup yang berorientasi pada nilai-nilai ketuhanan. Kehidupan spiritual merupakan kehidupan keseharian sesuai fitrah yang dimiliki manusia yakni untuk beribdah dan bertauhid kepada Allah SWT. Guru-guru terlebih dulu memberikan pengajaran kepada siswa siswi tentang pentingnya beribadah, guru melakukan pengawasan, mengajak serta memberikan teladan yang posistif kepada seluruh siswa dan siswi. Menjadi suri tauladan adalah sebuah keharusan bagi setiap guru, terlebih guru adalah seorang figur utama yang akan digugu dan ditiru langsung oleh siswa.

\section{b. Pembahasan}

1. Implementasi Program Emotional Spiritual Achievement (ESA) di SMAN 7 dan SMKN 1 Kota Tangerang Selatan

Program ESA sebuah program yang sifatnya membangun, membangun peserta didik menjadi anak-anak yang shaleh, berkepribadian baik dan berakhlaqul karimah, membangun kecintaan dan keimanan serta ketaqwaan terhadap Allah, ajaran-ajaran Islam, kebenaran adanya Allah dan lain sebagainya. 
Tujuan yang diharapkan dari kegiatan
ESA adalah membangun kecerdasan emosional dan spiritual bagi generasi muda. Dengan bekal tersebut pelajar mampu menyikapi dengan arif pola kehidupan yang semakin bebas dan berkembang, serta dapat merubah pola pikir para peserta didik terhadap segala permasalahn yang akan mereka hadapi di masa sekarang dan masa yang akan datang. Fungsi dari kegiatan ESA yakni lebih mengenal diri kita, memiliki empati terhadap sesame, senantiasa memiliki motivasi diri sendiri dan tidak gampang putus asa, selalu berfikir positif, siap menghadapi tantangan hidup yang semakin keras, dapat menghargai perasaan orang lain, tidak mudah egois, mudah ber-intropeksi diri. Pelaksanaan Program Emotional Spiritual Achievement (ESA) dilaksanakan di sekolah yang secara bergantian, pelaksanaannya berjalan selama dua hari pada hari libur yakni sabtu dan minggu, dengan beberapa sesi penyampaian materi sesuai tema yang ada di dalam buku modul ESA. Peserta yang mengikuti adalah siswa siswi yang masih aktif belajar di sekolah tersebut, tidak ada batasan maupun kelompok-kelompok yang di bagi dalam menyampaikan semua materi, semua adalah sama, dari kelas sepuluh sampai kelas dua belas mendapatkan materi yang sama. Dalam pelaksanaan program ESA tidak hanya siswa siswi yang berkesempatan mendapatkan banyak pengetahuan namun guru-guru yang hadir pun bisa mendapatkan ilmu pengetahuan dan wawasan yang bisa dijadikan rujukan maupun contoh ketika mengajar di kelas.

2. Faktor kelebihan dan kelemahan dalam pelaksanaan program Emotional Spiritual Achievement (ESA) di SMAN 7 dan SMKN 1 Kota Tangerang Selatan

Fator kelebihan dalam pelaksanaan ESA adalah kelebihan yang membuat program ini sangat di butuhkan oleh sekolah-sekolah, dengan beberapa kelebihan yang dimiliki program ESA ini dapat sangat membantu guru PAI dalam berjalannya pembelajarn di dalam kelas, guru lebih mudah dalam menyampaikan kepada peserta didik begtu pula peserta didik dapat dengan cepat menerima apa yang disampaikan oleh guru dalam menyampaikan materi.

Siswa siswi yang mengikuti Program Emotional Spiritual Achievement (ESA) tidak hanya dapat meningkatkan keimanan dan ketaqwaan kepada Allah saja namun mereka banyak belajar tentang moral, sifat-sifat baik dan tidak baik, cara berinteraksi dengan sesame kawan, menghindari pergaulan bebas dan maraknya hamil diluar nikah yang bisa mengancam siapa saja tanpa pandang usia. Karena dengan kita tidak memiliki cukup ilmu dan perhatian yang lebih dari berbagai pihak maka hal yang tidak diingikan akan terjadi. Dengan begitu kelebihan kelebihan yang ada pada Program Emotional Spiritual Achievement (ESA) ini membuat program begitu menarik dan unik, dengan berbagai materi dan penyampaiannya.

Sedangkan dengan kelemahan yang ada pada Program Emotional Spiritual Achievement (ESA) menjadikan Program Emotional Spiritual Achievement (ESA) bisa lebih baik dan terus meningkatkan kualitas program dengan menerima saran dan masukan sebagai bahan evalusi kedepan, dilihat kelemahan yang lebih sedikit dibandingkan kelebihan yang dimiliki Program Emotional Spiritual Achievement (ESA) pada pelaksanaannya maka tidak bisa kita katakan bahwa program ini tidak baik untuk diterapkan di sekolah maupun di lembaga lain, karena jelas program ini telah banyak melahirkan gagasan baru, inovasi baru bagi para guru dan struktural yang ada di sekolah, dengan adanya program ini peserta didik banyak mendapatkan pengetahuan dan ilmuilmu yang baru.

3. Peran guru PAl dalam mengembangkan kecerdasan Emotional Spiritual Achievement (ESA) di SMAN 7 dan SMKN 1 Kota Tangerang Selatan

Peran guru PAI dalam mengembangkan kecerdasan Emotional Spiritual Achievement (ESA) di sekolah sangatlah penting, guru harus mampu 
meneruskan dan mengembangkan apa yang telah siswa siswi terima ketika mengikuti Program Emotional Spiritual Achievement (ESA). Ada beberapa cara dan peran sebagai guru PAI dalam mengembangkan ESA di sekolah tersebut kepada siswa siswinya yakni ada berperan sebagai teladan yang akan ditiru peserta didik dari penampilan, kepribadiannya yang harus bisa sebagai contoh yang baik bagi mereka. Sebagian berperan sebagai pembimbing yang mampu membentuk peserta didik agar memiliki karakter akhlak yang baik, maka sebagai guru PAI hendaknya mencerminkan dalam kehidupan sehari-hari sebagai sosok guru yang mampu menjadikan siswa siswinya mengikuti dan mendengarkan apa yang telah dia bimbing. Berdasarkan berbagai peran guru di atas, ada beberapa prinsip yang secara tidak langsung sudah mengembangkan ESA kepada anak didiknya yakni semua siswa baik di SMKN 1 dan SMAN 7 diarahkan agar bisa lebih meningkatkan emosional dan spiritual dengan baik, cara berinteraksi dengan sahabat, guru, orang tua dan berinteraksi dengan sang khaliq Allah SWT.

Sekolah sebagai suatu lembaga pendidikan yang berfungsi menanamkan kesadaran di kalangan generasi milenial yang semakin berkembang dengan identitas mereka, serta memberikan kesadaran sebagai pelajar penerus bangsa yang memiliki karakter baik dan shaleh. Sementara itu guru adalah sebagai motivator, pembimbing, pengingat, pelatih para peserta didik dan memebrikan pendidikan moral dan agama, menanamkan sifat yang baik berbangsa dan bernegara.

\section{E. Kesimpulan}

Berdasarkan

keseluruhan pembahasan dan hasil temuan penelitian dan analisis tentang Program Emotional Spiritual Achievement (ESA) dalam Membentuk Pola Pikir Siswa Pada Mata Pelajaran PAl maka dapat diambil kesimpulan sebagai berikut:

1. Program ESA sangat penting untuk diterapkan dan diikuti oleh lembaga dan sekolah-sekolah yang ada di Indonesia, karena dengan adanya program ESA pihak sekolah maupun guru-guru khususnya guru PAl sangat terbantu dalam menjalankan kewajibannya sebagai guru pendidikan Agama Islam baik sebagai sosok yang harus menjadi seorang yang terlihat sempurna di dalam kelas maupun di luar kelas, membantu berjalannya kegiatan belajar mengajar karena dengan adanya program ESA anak telah mengetahui dan memahami pendidikan Agama. Dengan segala fungsi dan tujuan yang sifatnya membangun, tidak diragukan lagi bahwa program ESA memiliki khas tersendiri yang dapat memberikan kemudahan dan kemajuan bagi siswa siswi maupun sekolah yang mengikutinya.

2. Faktor kelebihan maupun kelemahan dalam program ESA tidak membuat program ini menjadi terbelakang, namun dengan lebih banyaknya kelebihankelbihan yang ada pada saat pelaksanaan ESA justru membuat program ini patut di dukung dan di terapkan di sekolah maupun lembaga lain. Faktor kelebihan program ESA salah satunya tumbuhnya kecintaan terhadap agama, kebenaran ajaran Islam, keimanan terhadap Allah, bukti nyata kebesaran Allah, kepercayaan diri yang kuat dan mampu mengubah pola pikir siswa terhadap pendidikan agama Islam. Sedangkan faktor kelemahannya hanyalah masalah waktu yang memungkinkan membuat anak bosan karena terlalu lama mengikuti program, kerena setiap individu siswa siswi berbeda-beda kepribadian. Dengan begitu penulis memberikan saran dan solusi dengan mengurangi durasi waktu pelaksanaan atau dengan menambah jadwal pelaksanaan yang awalnya dua tahun sekali menjadi tiga atau empat kali dalam setahun namun dengan waktu yang lebih pendek.

3. Peran guru PAI dalam mengembangkan kecerdasan emosional dan spiritual 
peran guru di SMKN 1 dan SMAN 7 Kota Tangerang Selatan dalam mengembangkan kecerdasan emosional dan spiritual secara tidak langsung sudah telah berhasil di kembangkan kepada peserta didik. Hal ini dilihat dari kegiatan belajar mengajar, sebagai motivator, pembingbing dan tauladan yang mampu menjadikan anak didiknya memiliki karakter yang baik, berakhlak terpuji, mengajarkan, mengingatkan akan jati dirinya, tugas dan sebagai seorang anak yang harus patuh terhadap kedua orang tua, dan yang paling penting adalah tetap menjaga keimanan dan ketaqwaan kepada Allah SWT. Sebagai guru terutama guru PAl harus mampu memahami setiap karakter siswa siswinya agar dapat mengarahkan, membimbing dan membina dengan baik. Selain itu harus ada interaksi antara siswa dan guru serta setiap orang yang ada disekolah.

\section{DAFTAR PUSTAKA}

Ahmad Noval, Shofyan Affandi, dkk.(2016). Program Pelajar Jakarta Berkarakter. Surabaya: Yayasan Al-Kahfi

Ary Ginanjar Agustian. (2002). ESQ Power, Jakarta: Arga,

Abdul Basyit dan Sahlani. (2017). Ilmu Pendidikan Islam. Banten: Pustaka Getok Tular

Abdul Jalil. (2013). Spiritual Entrepreneurship. Yogyakarta: Lkis

Abdul Majid dan Juyuf Mudzakkir. (2006). Ilmu Pendidikan Islam. Jakarta: Kencana Prenada Media

Abdul Majid dan Andayani. (2005). Pendidikan Agama Islam Berbasis Kompetensi. Bandung: Remaja Rosda Karya

Abudin Nata. (2013). Metodologi Studi Islam. Jakarta: Rajawali pers
Ahmad Tafsir. (2005). Ilmu Pendidikan Dalam Pespektif Islam. Bandung: PT. Remaja Rosdakarya

Bogdan C. R. and Biklen S. K. Quantitative Research for Education: An Introduction to Theory and Methods. Terj. Munandir. (1990). Jakarta: Direktorat Jenderal Pendidikan Tinggi Departemen Pendidikan dan Kebudayaan.

Bogdan C. R. and Taylor. (1993). Introduction In Qualitative Research Methods. New York: John Wiley \& Son Inc.

Creswell, John W. (1994). Qualitative and Quantitative Approaches. LondonNew Delhi: Sage Publication.

Creswell, John W. (1998). Qualitative Inquiry and Research Design: Choosing among Five Tradision. New Delhi: Sage Publication.

Creswell, John W. (2008). Educational Research. New Jersey: Pearson Education. Third Edition.

Cooper dan A. Sawaf. (1998). Kecerdasan Emosional dalam Kepemimpinan Organisasi. Jakarta: Gramedia Pustaka Utama

Djohan Untung. (2006). Kamus Lengkap Inggris-Indonesia. Edumasa Indonesia

Daniel Goleman. (2001). Kecerdasan emosi Untuk Mencapai Puncak Prestasi. Jakarta: Gramedia Puskta Utama

Danah Zohar dan Ian Marshall. (2001). SQ: memanfaatkan kecerdasan spiritual Dalam Berpikir Integritas dan Holistik untuk Memaknai Kehidupan. Bandung: Mizan

Departeman Pendidikan Dan Kebudayaan. (1995). Kamus Besar Bahasa Indonesia, Jakarta: Balai Pustaka.

Deddy Mulyana. (2004). Metodologi Penelitian Kualitatif, Bandung: PT Remaja Rosdakarya. 
Hamdani Bakran Adz Zakiy. (2004). Kecerdasan Kenabian Menumbuhkan Potensi Hakiki Insani Melalui Pengembangan Kesehatan Ruhani. Yogyakarta: Islamika

Isabelle Baszanger dan Nicolas Dodier. (2010). "Ethnography: Relating the Part to the Whole", dalam David Silverman (Ed.), Qualitative Research: Theory, Method, and Practice, London, Thousand Oaks, New Delhi: Sage Publication.

Jamali Sahroni. (2008). Filsafat Pendidikan Islam. Bandung: Arfini Raya

Kementrian Agama Republik Indonesia. (2015). Al-Qur'an dan Terjemah Al-Fattaah. Depok: Yakfi

Lexy J. Moleong.(1998). Metodologi Penelitian Kualitatif, Bandung: PT. Remaja Rosdakarya, cet. ke 9.

La Ode Sismono. (2006). Di Belantara Pendidikan Bermoral. Yogyakarta: UNY Press

Mustafa Fahmi. (1997). Kesehtan Mental di Lingkungan Keluarga, Sekolah dan Masyarakat. Jakarta: Bulan Bintang

Mustafa Fahmi. (1986). Pokok-Pokok Kesehatan Jiwa/Mental. Bulan Bintang

M. Arifin. (2003). Ilmu Pendidikan Islam. Jakarta: Bumi Aksara

M. Usman Najati. (2001). Al-Qur'an dan Psikologi. Jakarta: Asas Pustaka

Masri Singarimbun. (1989). Metode Penelitian Survai, Jakarta : LP3ES.

Noeng Muhadjir. (1996). Metodologi Penelitian Kualitatif, Yogyakarta: Rake Sarasin, Edisi III.

Noeng Muhajir.(1998). Metode Penelitian Kualitatif, Yogyakarta: Rakesarasin, edisi ke-3, cet. ke-8,
Purma Atmaja Prawira. (2012). Psikologi Pendidikan dalam Perspektif Baru. Jogjakarta: Ar-Ruzz Media

Pupuh faturrahman. Cet K-1. Belajar Mengajar Melalui Penanaman Konsep Umum dan Konsep Islami. Bandung: PT Strategi Rafika Adita

Rukaesih A. Mauolani dan Ucu Cahyana. (2016). Metodologi Penelitian Pendidikan Jakarta: Rajawali pers

Sugiyono. (2009).Memahami Penelitian Kualitatif, Bandung: Simbiosa.

Suharsimi Arikunto.(1990).Prosedur Penelitian, Yogyakarta: Rineka Cipta.

Suharsimi Arikunto. (2002). Prosedur Penelitian suatu Pendekatan Praktek, Jakarta: PT. Rineka Cipta, cet. ke 5 .

Suharsimi Arikunto. (2013). Prosedur Penelitian suatu penelitian pendekatan. Jakarta: Rineka Cipta

Steven J Stein. (2002). Ledakan EQ: 15 Prinsip Dasar Kecerdasan Emosional Meraih Sukses. Bandung: Kaifa

Toto Tamara. (2001). Kecerdasan Ruhaniah. Jakarta: gema Insani press

Umairso. (2011). Kepemimpinan dan Kecerdasan Spiritual. Jogjakarta: Ar-Ruzz Media

V.Wiratna Sujarweni. (2014). Metodologi Penelitian Lengkap, Praktis dan Mudah Dipahami, Yogyakarta: Pustakabarupress

Wawancara pribadi dengan ketua panitia pelaksana program ESA, 7 September 2019

Zakiah Drajat. (2012). Ilmu Pendidikan Islam. Jakarta: Bumi Aksara 
Program Emotional Spiritual Achievement (Esa) Dalam Membentuk Pola Pikir Siswa Pada Mata Pelajaran Pendidikan Agama Islam Di Kota Tangerang Selatan 